\title{
LUNG FUNCTION AND ACID-BASE BALANCE IN THE NEWBORN INFANT
}

\author{
AKADEMISK AVHANDLING \\ SOM MED BENÄGET TILLSTẢND AV \\ UNIVERSITETSKANSLERSÄMBETET \\ FÖR ERNÅENDE AV MEDICINE DOKTORSGRAD \\ OFFENTLIGEN FÖRSVARAS I \\ VÄSTERBOTTENS LÄNS LANDSTINGS SJUKSKÖTERSKESKOLAS AULA \\ FREDAGEN DEN 22 MARS KL. 13.30
}

\author{
AV \\ G ÜN TER K OCH \\ LEG. LÄK.
}



From the Departments of Clinical Physiology and Pediatrics, University of Umea, and the Department of Pediatrics, Karolinska Hospital, University of Stockholm, Sweden

\title{
LUNG FUNCTION \\ AND ACID-BASE BALANCE \\ IN THE NEWBORN INFANT
}

\author{
BY \\ G ÜNTER KOCH
}


Supported by grants from the Faculty of Medicine, University of Umeå. 


\section{CONTENTS}

PREFACE . . . . . . . . . . . . . . . . . . . . . . 5

INTRODUCTION . . . . . . . . . . . . . . . . . . . 7

MATERIAL . . . . . . . . . . . . . . . . . . . . . . . . 9

METHODS . . . . . . . . . . . . . . . . . . . . . 10

Mechanics of breathing and pulmonary ventilation . . . . . . . . 10

Functional residual capacity . . . . . . . . . . . . . . . . 10

Steady state pulmonary ventilation and diffusing capacity . . . . . . 10

Venous admixture . . . . . . . . . . . . . . . . . . . 11

Blood collection . . . . . . . . . . . . . . . . . . . . 11

Blood analyses . . . . . . . . . . . . . . . . . . . . 12

Gas analyses . . . . . . . . . . . . . . . . . . . . . 13

RESULTS . . . . . . . . . . . . . . . . . . . . . . 14

The onset of breathing in terms of pulmonary ventilation and mechanics of breathing. . . . . . . . . . . . . . . . . . . . 14

Further development of the mechanical properties of the lung during the first week of life . . . . . . . . . . . . . . . . . . 15

Functional residual capacity . . . . . . . . . . . . . . . 16

Blood gases and acid-base balance during the first week . . . . . . 16

Venous admixture due to true anatomic shunt during the first week of life 18

Steady state pulmonary ventilation and diffusing capacity . . . . . . 19

$\mathrm{A}$-a $\mathrm{O}_{2}$ difference and total venous admixture . . . . . . . . . . . 19

Cardiac output and overall ventilation/perfusion ratio . . . . . . . 19

DISCUSSION . . . . . . . . . . . . . . . . . . 22

Methods . . . . . . . . . . . . . . . . . . . . . . 22

Onset of respiration and initial respiratory adjustment . . . . . . . 22 
Further development of pulmonary mechanics and lung volume . . . . 24 "Late" adjustment of intrapulmonary gas exchange . . . . . . . . 26 Acid-base balance . . . . . . . . . . . . . . . . . . . 29

SUMMARY . . . . . . . . . . . . . . . . . . . . . 31

RÉSUMÉ . . . . . . . . . . . . . . . . . . . . . . 33

ZUSAMMENFASSUNG . . . . . . . . . . . . . . . . . . 35

REFERENCES . . . . . . . . . . . . . . . . . . . . 38

APPENDIX . . . . . . . . . . . . . . . . . . . 41 


\section{PREFACE}

This survey is based on the following individual papers which will be referred to with their consecutive numbers.

I. Karlberg, P., Cherry, R. B., Escardó, F. E. and Koch, G.: Respiratory studies in newborn infants. II. Pulmonary ventilation and mechanics of breathing in the first minutes of life, including the onset of respiration.

Acta Pædiatrica Scandinavica 51: 121136, 1962.

II. Karlberg, P. and Koch, G.: Respiratory studies in newborn infants. III. Development of mechanics of breathing during the first week of life. A longitudinal study.

Acta Pædiatrica Scandinavica, suppl. 135: 121-129, 1962.
III. Geubelle, F., Karlberg, P., Koch, G., Lind, J., Wallgren, G. and Wegelius, C.: L' aération du poumon chez le nouveauné.

Biologia Neonatorum 1: 169—210, 1959.

IV. Koch, G. and Wendel, H.: Adjustment of arterial blood gases and acid base balance in the normal newborn infant during the first week of life.

Biologia Neonatorum 12: 136-161, 1968.

V. Koch, G.: Venous admixture due to true anatomic shunt in the newborn infant during the first week of life.

Pädiatrie und Pädologie 4:1968 (in press).

VI. Koch, G.: Alveolar ventilation, diffusing capacity and the $\mathrm{A}-\mathrm{a} \mathrm{PO}_{2}$ difference in the newborn infant.

Respiration Physiology 4:168_192, 1968. 



\section{INTRODUCTION}

Successful transition from intra- to extrauterine life is dependent on the readjustment of a great number of functions to be accomplished more or less urgently during and following delivery. Among these adaptative processes the most dramatic changes are those occurring in the circulatory and respiratory system. The readjustment processes occurring in these two systems are intimately linked together and interdependent.

In the fetus, gas exchange is exclusively achieved with the maternal circulation by means of the placenta. The lungs do not contain any gas. However, the alveoli are ail open to some degree (Potter, 1953; Plank, 1967) and appear at term to be equally expanded with liquid (Plank, 1967). This liquid differs in $\mathrm{pH}$, total osmolality, total $\mathrm{CO}_{2}$, prutein, sugar, urea and electrolyte concentration from amniotie fluid (Adams et al., $1963 \mathrm{a}$; Adams et al., 1963 b). These differences and persisting liquid formation despite artificially induced tracheal obstruction (Carmel et al., 1965) suggest that it may be an ultrafiltrate of blood, with selective reabsorption or secretion by the lung (Adams et al., $1963 \mathrm{~b}$ ). There is an open communication between the alveoli and the surrounding amniotic fluid (Potter, 1953). Intrauterine respiratory movements may occur (cf. Smith, 1959), but do not seem to be a regular event. As gestation proceeds, they become rarer and the stimuli producing them are less effective.
Blood flow through the lungs is low. In the sheep fetus at term only about 12 per cent of the total cardiac output goes to the lungs (Dawes, 1958). Marked fluctuations due to changes in vasomotor tone and probably related to, among other factors, blood gas composition, may, however, occur (Dawes and Mott, 1962; Cook et al., 1963).

The low pulmonary perfusion is due to high vascular resistance in the pulmonary circulation in relation to the resistance in the systemic-placental circulation, and most of the blood in the pulmonary trunk is deflected through the ductus arteriosus into the descending aorta. In the fetal lamb at term, more than 50 per cent of the total aortic flow comes directly from the right ventricle and passes through the ductus arteriosus (Dawes et al., 1953). The left atrium mainly receives blood directly from the inferior vena cava through the foramen ovale. Thus the blood by-passes the high-resistance pulmonary circuit, and both ventricles work in parallel behaving as a functionally single ejection system, pumping blood into the low resistance systemic-placental circulation (Lind and Wegelius, 1954; Lind, 1965). In the lamb, more than 50 per cent of the combined output is directed to the placenta (Dawes, 1958).

When the placental circulation is eliminated at birth the inactive fetal lungs have to take over the function of the placenta as an effective gas exchanger to ascertain sur- 
vival in the new enviroment. This requires

1) the more or less immediate expansion and aeration of the lungs and opening-up of the pulmonary circulation,

2) the continued ventilation of the opened alveoli and establishment of an adequate perfusion of the pulmonary vascular bed,

3) the adjustment of distribution of alveolar ventilation and perfusion to each other and establishment of sufficient capacity for diffusion of the respiratory gases through the alveolar-capillary membrane.

The transition to extrauterine life thus implies the establishment of a new autonomic function - that of pulmonary respiration, and important changes in the distribution of cardiac output.

The present series of studies was performed to elucidate some of the mechanisms involved in this establishment and to evaluate the efficiency of lung function in the healthy fullterm newborn infant. It is mainly a study of mechanics of breathing, aeration of the lungs in terms of functional residual capacity, pulmonary ventilation and diffusion, efficiency of gas exchange in terms of arterial blood gases and alveolar-arterial oxygen tension gradients, and acid-base balance. Emphasis is laid on development of function.
Since available reports of neonatal lungfunction studies are mainly focused on the first minutes and hours of extrauterline life, the present studies have been extended to include the entire first week of life.

Respiratory problems present the major threats to survival of the newborn infant (Driscoll and Smith, 1962). They are overwhelmingly the consequence of the infant's failure to complete successfully the respiratory and circulatory adaptation from intrato extrauterine life. Knowledge of the physiological conditions underlying the normal neonatal respiration and its adjustment is a prerequisite for evaluation of the failing mechanisms and for all rational therapeutic measures. Thus all studies aiming at increasing our knowledge of the respiratory and circulatory adjustment have had and continue to have direct practical clinical implications. It was under this conception that the reported studies were commenced and conducted.

The need for miniaturization of methods and apparatus and the complete lack of cooperation of the subject to be studied are serious problems to be overcome in pulmonary function investigation in the neonatal period; therefore methodological details and reproducibility of methods have been emphasized. 


\section{MATERIAL}

Since the purpose of the present investigation was to analyse normal neonatal respiratory function, the subjects of the different studies are fullterm infants who were selected at random. With but a few exceptions, the infants had a spontaneous vertex delivery and were normal as regards pregnancy, gestational age, labour, birth weight, onset of respiration and clinical course during the neonatal period. The cord was in general clamped after cessation of visible pulsations. However, case No. 71 (I) had a somewhat delayed first breath, No. 78 (I) a birthweight of only $2360 \mathrm{~g}$. Study II and III include some otherwise healthy prematures with a birthweight between 1290 and $2180 \mathrm{~g}$. Two cases required earlier clamping because the cord was ruptured during the delivery (II), or was twisted around the neck (VI).

No analgesia was used during labour; in the first series of studies (I, II, III), however, a chloroform anaesthesia of very short duration was given at the end of the delivery, and some of the mothers received intermittent nitrous oxide during contractions during the latter part of labour. In the second group of infants (IV, V, VI) most mothers received nitrous oxide or trichlorethylene, or both, by inhalation of short duration at the end of the delivery.

A total of 172 infants were studied. 


\section{METHODS ${ }^{*}$}

This survey gives only an enumeration of the methods used. For a more detailed description the reader is referred to the original papers.

\section{MECHANICS OF BREATHING AND \\ PULMONARY VENTILATION (I, II, III)}

Tidal volume $\left(\mathrm{V}_{\mathrm{T}}\right)$ and respiratory rate $(\mathrm{f})$ were determined by means of a "reverse" body plethysmograph, connected to the infant by a face mask (III; Karlberg, Cherry, Escardó and Koch, 1960). The volume changes were recorded by means of an inductive pressure transducer amplifier unit (Elema-Schönander) on an ECG direct recorder (Mingograph 42). Flow rate (V) was derived from the volume curve by means of a specially designed electronic device (Karlberg, Cherry, Escardó and Koch, 1960).

Intraoesophageal pressure was recorded by means of a liquid filled polyethylene catheter, $1 \mathrm{~mm}$ inside diameter with several holes near the tip over another pressure transducer amplifier unit on a third channel of the Mingograph.

\section{FUNCTIONAL RESIDUAL CAPACITY} (FRC) (III)

The FRC was determined by means of the closed-circuit method with helium as test gas. A nasal coupling was used for connecting the infant to the breathing system.
STEADY STATE PULMONARY VENTILATION AND DIFFUSING CAPACITY (VI)

The breathing circuit used was built according to the box-balloon principle and consisted mainly of a glas box serving as a "reverse" plethysmograph enclosing the inspiratory and expiratory bag. The respiratory pressure variations were recorded on a Mingograph 42 as described above.

A low resistance gravity independent breathing valve was developed. The dead space was 0.8 and ca. $1.7 \mathrm{ml}$ when used in connection with a nasal coupling and a face mask respectively.

The pulmonary diffusing capacity was determined with the steady state carbon monoxide method (Filley et al., 1954) as modified by Linderholm (1957) and calculated from the equation

$$
\mathrm{DLCO}=\dot{\mathrm{V}}_{\mathrm{CO}} /\left(\overline{\mathrm{P}}_{\mathrm{ACO}}-\overline{\mathrm{P}}_{\mathrm{CCO}}(1)\right.
$$

The pulse rate was calculated from the simultaneously recorded ECG.

Effect of the investigation procedure on the infants' basal state: No significant changes, either in respiratory or in heart rate, were induced by application of the breathing mask. $\mathrm{PaCO}_{2}(\mathrm{p}<0.001)$ and standard bicarbonate $(\mathrm{p}<0.05)$ were, however, slightly higher and $\mathrm{pH}(\mathrm{p}<0.001)$ and $\mathrm{Pa}_{2}$ $(p>0.05)$ slightly lower during than before the sampling procedure. During the sampling

*) Symbols used are those suggested in report in Fed. Proc. 9: 602, (1950). 
period itself, respiratory and heart rate were virtually unchanged.

The reproducibility of the most important data measured and calculated in connection with the determination of DiCO, when examinations at 24 hours and 7 days respectively are considered as duplicate determinations, were in the same order as in resting adults (Table IV).

VENOUS ADMIXTURE (V, VI)

Venous admixture (Qs/Q) was calculated from the classical shunt formula after due transformations with the assumption of an unchanged arterial-mixed venous oxygen difference of $3.5 \mathrm{ml} / 100 \mathrm{ml}$ blood during both air and 100 per cent oxygen breathing and during the period of observation.

1) Total venous admixture or "physiologic" shunt (including both anatomic shunt and venous admixture from alveoli with low ventilation/perfusion ratio was estimated during air breathing from the formula:

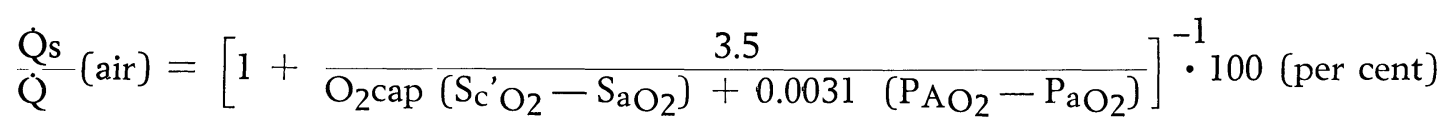

where 0.0031 is the amount of oxygen physically dissolved in $100 \mathrm{ml}$ blood per $\mathrm{mm} \mathrm{Hg}$ $(\mathrm{V}, \mathrm{VI})$.

2) Venous admixture due to anatomic right-to-left shunt was estimated during breathing of pure oxygen after washing-out of nitrogen. Oxygen breathing was performed during 20 minutes in a specially constructed plexiglass hood approximately fitting the infant's head.

Provided arterial $\mathrm{PO}_{2}>150 \mathrm{~mm} \mathrm{Hg}$, at which tension hemoglobin may be considered completely saturated, the equation used was:

$$
\left.\frac{\mathrm{Q} s}{\mathrm{Q}} \text { (oxygen }\right)=\left[1+1129 /\left(\mathrm{PAO}_{2}-\mathrm{PaO}_{2}\right)\right]^{-1} \cdot 100 \text { (per cent) }
$$

When $\mathrm{PaO}_{2}$ was below $150 \mathrm{~mm} \mathrm{Hg}$ equation (3) was not considered to be valid and the following equation was used:

$$
\frac{\mathrm{Q} s}{\mathrm{Q}} \text { (oxygen) }=\left[1+\frac{3.5}{\mathrm{O}_{2} \mathrm{cap}\left(1-\mathrm{S}_{\mathrm{aO}_{2}}\right)+0.0031\left(\mathrm{P}_{\left.\mathrm{AO}_{2}-\mathrm{P}_{\mathrm{aO}_{2}}\right)}\right.}\right]^{-1} \cdot 100 \text { (per cent) }
$$

A nomogram for the $\mathrm{P}_{\mathrm{O}_{2}}$ ranges above and below $150 \mathrm{~mm} \mathrm{Hg}$ permitting easy estimation of anatomic shunt ( $Q$ s/Q) from arterial oxygen tension during breathing of 100 per cent oxygen is given in Fig. 1.

Cardiac output (Q) (VI) was estimated from the actually measured oxygen consumption $\left(\mathrm{V}_{2}\right)$ and the assumed value of 3.5 $\mathrm{ml} / 100 \mathrm{ml}$ blood for the arterial - mixed venous oxygen difference using Fick's formula:

$$
\dot{Q}=\left(\dot{\mathrm{V}}_{2} / 3.5\right) \cdot 100(\mathrm{ml})
$$

\section{BLOOD COLLEC'TION (IV, V, VI)}

Since capillary blood is not a reliable substitute for arterial blood during the neonatal period particularly with respect to $\mathrm{P}_{\mathrm{O}_{2}}$ (Koch and Wendel, 1967 a) arterial blood had to be collected. In order to avoid disturbance of "steady state" conditions, blood sampling had to be performed by means of an indwelling arterial catheter.

Arterial blood was sampled from the descending aorta by means of a polyvinyl ca- 
FIG. 1. Nomogram for calculating anatomic shunt ( $\mathrm{Q} s / \mathrm{Q})$ from arterial oxygen tension $\left(\mathrm{P}_{\mathrm{aO}_{2}}\right)$ during 100 per cent oxygen breathing.

Left side nomogram for oxygen tensions above $150 \mathrm{mmHg}$, right side nomogram for oxygen tensions below $150 \mathrm{mmHg}$. (Nomograms are based on the assumptions of $\mathrm{P}_{\mathrm{AO}_{2}}=673 \mathrm{mmHg}$, arterio-venous $\mathrm{O}_{2}$ difference $=3.5 \mathrm{ml} / 100 \mathrm{ml}, \mathrm{O}_{2}$ cap $=23 \mathrm{ml} /$ $100 \mathrm{ml}$ ) (V).

theter (feeding tube French size 5) inserted in one of the umbilical arteries within 15 minutes after delivery and left in place for maximally 7 days. With the technique used this procedure was considered free of risk and no complications caused by the catherization were observed (Koch and Wendel, 1967 b).

Whenever cord blood was sampled (IV) the umbilical artery and subsequently the umbilical vein were directly punctured without clamping the cord.

Blood samples between 1 and $5 \mathrm{ml}$ each were collected in $5 \mathrm{ml}$ heparinized syringes and immediately iced.

\section{BLOOD ANALYSES (IV, V, VI)}

Blood gas analyses and determination of $\mathrm{pH}$ were performed within 60 minutes after sampling, $\mathrm{PaO}_{2}$ and $\mathrm{PaCO}_{2}$ after oxygen breathing were determined immediately.

$\mathrm{pH}$ was measured at $37^{\circ} \mathrm{C}$ with a thermostated microglass electrode. The same standard phosphate buffer solution (Koch 1965) was used throughout the study.

Carbon dioxide tension $\left(\mathrm{Pa}_{\mathrm{CO}_{2}}\right)$ was determined with a Severinghaus-type electrode (Severinghaus and Bradley, 1959) and oxygen tension $\left(\mathrm{PaO}_{2}\right)$ with a Clark-type microelectrode (Clark, 1956) with a polypropylene membrane. During a part of the studies (VI) carbon dioxide tension was also
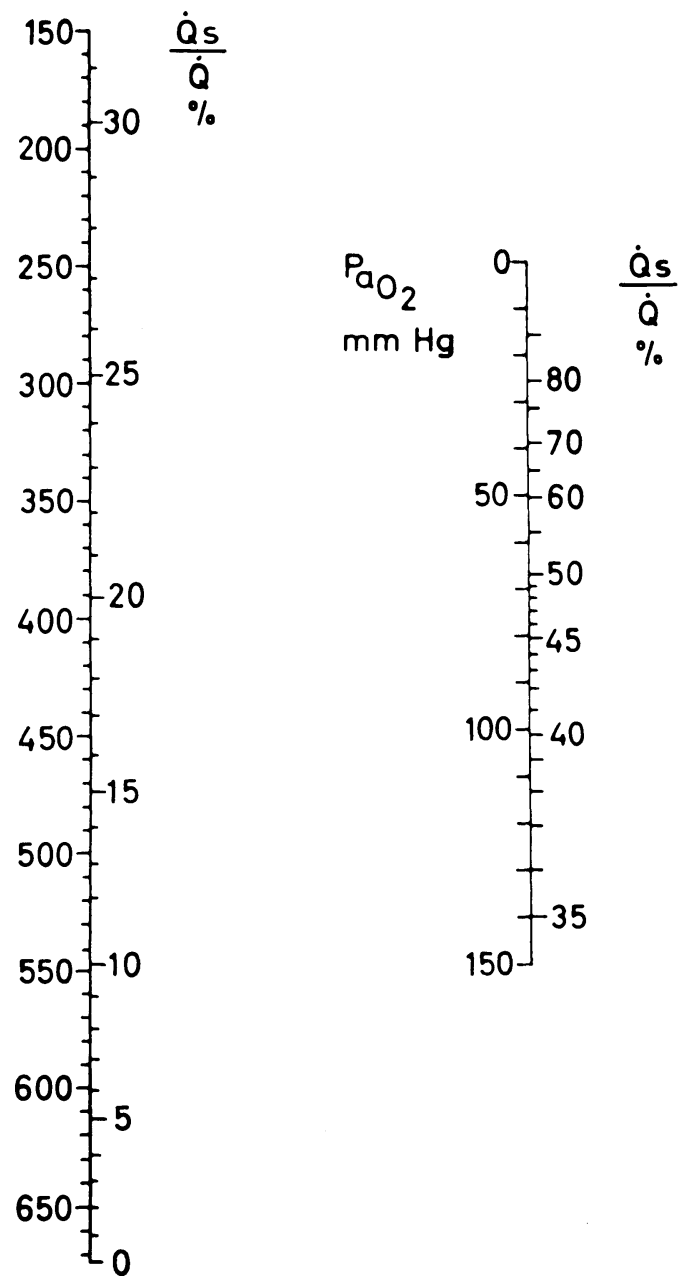

measured by the microequilibration technique (Siggaard-Andersen et al., 1960).

Standard bicarbonate and total $\mathrm{CO}_{2}$ content were determined by the microequilibration technique or by use of the SiggaardAndersen's alignment nomogram (1963). The validity of this nomogram for neonatal blood was shown by determining the first dissociation coefficient of carbonic acid in umbilical venous blood, and comparing total $\mathrm{CO}_{2}$ content determined directly by the manometric Van Slyke technique with the values obtained from the alignment nomogram (IV).

Oxygen saturation $\left(\mathrm{S}_{\mathrm{O}_{2}}\right)$ and hemoglobin concentration $(\mathrm{Hb})$ were measured spectro- 
photometrically, the hematocrit (Hct) was determined by microcapillary technique. Oxygen capacity $\left(\mathrm{O}_{2}\right.$ cap) was derived from hemoglobin concentration assuming $1 \mathrm{~g}$ hemoglobin to combine with $1.34 \mathrm{ml} \mathrm{O}_{2}$ STPD (IV).

Lactic acid concentration was determined enzymatically (IV) and pyruvic acid concentration by the method of Friedeman and Haugen (1943), as modified by Huckabee (1956).

Carbon monoxide content (VI) of arterial blood was determined in $0.1 \mathrm{ml}$ samples by microtechnique (Linderholm, 1965).

\section{GAS ANALYSES (VI)}

Fractions of oxygen, carbon dioxide and nitrogen in inspiratory and exspiratory gases were determined according to Scholander (1957). Carbon monoxide in the gas phase was measured with a hopcalite CO-meter (I.inderholm and Sjöstrand 1956).

For the most important analytical procedures used in this series of studies, methodological errors expressed as the standard error of a single determination ( $\mathrm{Sx}$ ) and the coefficient of variation ( $v$ ) calculated from duplicate determinations are given in Table $\mathrm{I}$.

TABLE I.

Reproducibility of some analytical methods estimated from duplicate determinations (IV, V, VI).

\begin{tabular}{llllllll}
\hline Variable & Dimensions & Method & $\mathrm{n}$ & $\overline{\mathrm{x}}$ & $\overline{\mathrm{d}}$ & $\mathrm{Sx}$ & $\mathrm{v}$ \\
\hline $\mathrm{pH}$ & units & microelectrode $^{1}$ & 80 & 7.327 & 0.0002 & 0.0022 & \\
$\mathrm{P}_{\mathrm{aCO}}$ & $\mathrm{mm} \mathrm{Hg}$ & microelectrode $^{2}$ & 84 & 35.9 & 0.06 & 0.6 & 1.6 \\
$\mathrm{PaO}_{2}$ & $\mathrm{~mm} \mathrm{Hg}$ & microelectrode $^{2}$ & 84 & 60.6 & 0.1 & 0.7 & 1.2 \\
$\mathrm{~S}_{\mathrm{aO}}$ & per cent & spectrophotom. $^{3}$ & 50 & 81.4 & 0.3 & 1.3 & 1.6 \\
$\mathrm{Hb}$ & g/100 ml & spectrophotom. $^{4}$ & 44 & 15.05 & 0.016 & 0.1 & 0.7 \\
$\mathrm{Hct}$ & per cent & micromethod & 50 & 50.9 & 0.13 & 0.3 & 0.6 \\
Lactic acid & meq/1 & enzymatic & 50 & 2.4 & 0.02 & 0.12 & 5.1 \\
Pyruvic acid & meq/1 & & 30 & 0.14 & 0.0013 & 0.003 & 2.18 \\
$\mathrm{C} \mathrm{CO}$ & vol. per cent & micromethod & 44 & 0.57 & $4.6 \times 10^{-3}$ & $1.3 \times 10^{-2}$ & 2.3 \\
$\mathrm{FCO}_{\mathrm{CO}}$ & vol. per cent & hopcalite & 44 & $4.7 \times 10^{-2}$ & $1.2 \times 10^{-4}$ & $5.6 \times 10^{-4}$ & 1.2 \\
& & & 44 & $9.7 \times 10^{-2}$ & $1.8 \times 10^{-4}$ & $9.1 \times 10^{-4}$ & 0.9 \\
$\mathrm{FO}_{2}$ & vol. per cent & Scholander & 44 & 20.81 & $3.8 \times 10^{-3}$ & $1.9 \times 10^{-2}$ & $9.6 \times 10^{-2}$ \\
& & & 44 & 16.91 & $3.1 \times 10^{-3}$ & $2.3 \times 10^{-2}$ & 0.13 \\
$\mathrm{FCO}_{2}$ & vol. per cent & Scholander & 44 & 3.11 & $7 \times 10^{-3}$ & $1.9 \times 10^{-2}$ & 0.64
\end{tabular}

$\mathrm{n}=$ number of duplicate determinations

$\overline{\mathrm{x}}=$ mean value

$\overline{\mathrm{d}}=$ mean difference between duplicate determinations

$\mathrm{S} \mathbf{x}=$ standard error of a single determination

$\mathrm{v}=$ coefficient of variation, per cent
1) Radiometer
2) Instrumentation Laboratory
3) Beckman D
4) Eppenhoff
5) Stålex 


\section{RESULTS}

THE ONSET OF BREATHING IN TERMS OF PULMONARY VENTILATION AND MECHANICS OF BREATHING (I)

Changes prior to the first breath:

Among 10 cases in whom a record prior to the first breath was obtained, in 3 instances inspiratory and in 5, expiratory volume changes amounting to $5-25 \mathrm{ml}$ were recorded, in general accompanied by slight changes in intraoesophageal pressure.

\section{First breaths:}

In 10 cases (Case No 71 excluded) where the first breath could be recorded this occurred between 6 and 55 seconds counted from the moment when the head was outside the vulva. The volume displacement effected by the first breath ranged between 12 and 67 $\mathrm{ml}$, the maximal intraoesophageal pressure changes during inspiration ranged between -4 and $-70 \mathrm{~cm} \mathrm{H}_{2} \mathrm{O}$ and during expiration between +5 and $+70 \mathrm{~cm} \mathrm{H}_{2} \mathrm{O}$. The subsequent breaths had in general a similar pressure volume pattern but showed a tendency toward decreased magnitudes in both pressure and volume. The total intrathoracic pressure swing during the first breath ranged from 40 to $100 \mathrm{~cm} \mathrm{H}_{2} \mathrm{O}$.

\section{Residual volume:}

In 7 of 11 infants the end expiratory level of the first breath was between 4 and $30 \mathrm{ml}$ higher than the inspiratory starting level and was mainly maintained at this higher level during the subsequent breaths. This volume shift is consistent with the build-up of a residual volume. In two cases the end expiratory level was constant, in two (Nos 48 and $66)$ it was by 7 and $9 \mathrm{ml}$ respectively lower than the starting level. In these two infants some "expiratory" volume change had been recorded prior to the first breath which suggests that some volume gain may have occurred before recording was started.

Initial breathing pattern, respiratory rate and 20 seconds' ventilation:

There were mainly 3 patterns of initial respiration: 1) regular rhythmic respiration with a relatively high respiratory rate $(>25 / \mathrm{min})$ 2) regular periodic breathing and 3 ) breathing with irregular periodicity. Accordingly, respiratory rate showed large variations and the initial 20 seconds' ventilation ranged between 78 and $790 \mathrm{ml}$.

\section{Mechanical factors:}

Pressure volume diagrams (respiratory loops) of the first breath and in general even the subsequent breaths had a more or less quadratic form indicating high pulmonary resistance and probably, at least in most cases, low lung compliance. Variations in the magnitude of negative and positive pressures necessary, and their relationship to each other, were, however, large. According to 


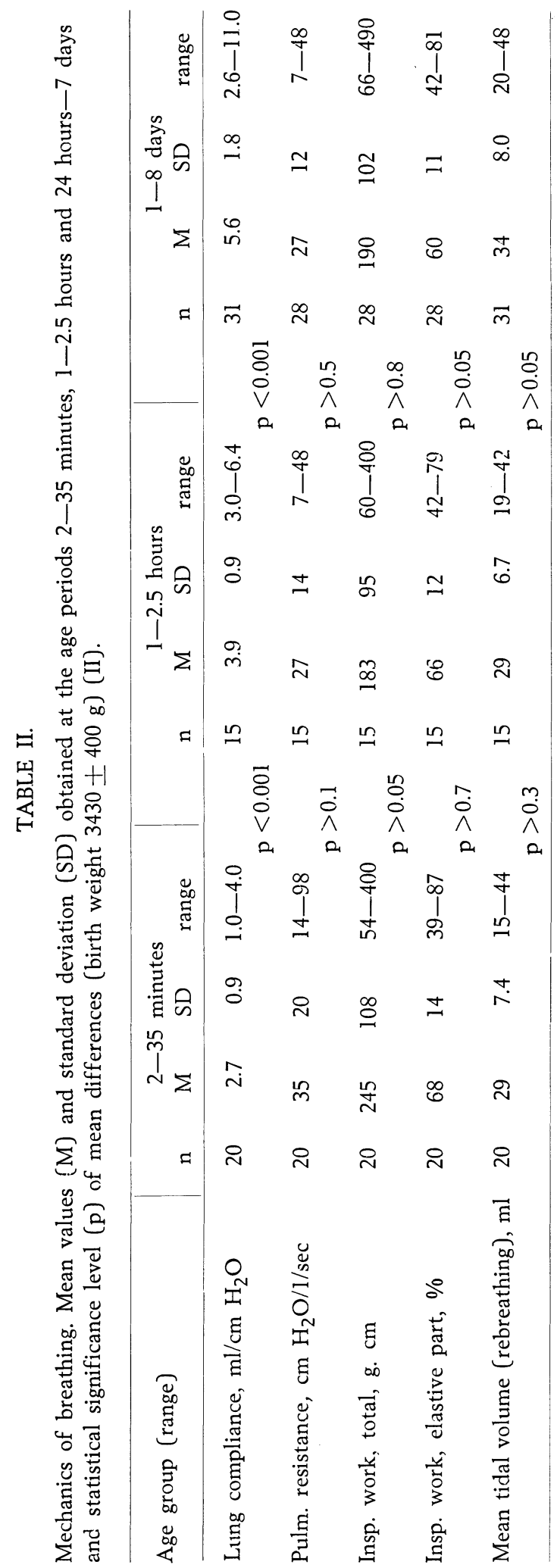

the magnitude of inspiratory pulmonary resistance, two rather distinct groups can be separated, one with rather low and the other with higher resistance. The group with the lower inspiratory pulmonary resistance appears to have a tendency towards higher compliance.

Inspiratory work during the first breaths in relation to tidal volume is significantly higher than during quiet breathing, but of the same order as during crying in newborns at the age of some days.

\section{FURTHER DEVELOPMENT OF THE MECHANICAL PROPERTIES OF THE LUNG DURING THE FIRST WEEK OF LIFE (II)}

As early as at the age of $2-3$ minutes, i. e. after approximately $40-100$ breaths, the respiratory loops during quiet breathing are smaller and volume and pressure variations less. Lung compliance increases and pulmonary resistance, total inspiratory work and the part of inspiratory work done to overcome elastic forces decrease. There is a fairly rectilinear relationship between compliance, pulmonary resistance, inspiratory work $/ \mathrm{VT}^{2}$ respectively and age when plotted on a double logarithmic scale. This means that changes proceed most rapidly in the very beginning of extrauterine life, and only insignificant changes occur during the period between 24 hours and 8 days of age. In eleven infants studied both at 24 hours and 7 days, there were no statistically significant differences between the values obtained at the two ages $\left(\mathrm{V}_{\mathrm{T}}: \overline{\mathrm{D}}\right.$ [8 days -24 hours] $=1 \pm 9 \mathrm{ml}^{*}$, $\mathrm{p}>0.6$ ), lung compliance: $\overline{\mathrm{D}}=0.9 \pm 2.8$ $\mathrm{ml} / \mathrm{cm} \mathrm{H}_{2} \mathrm{O}, \mathrm{p}>0.3$, pulmonary resistance: $\overline{\mathrm{D}}=-2.6 \pm 12.1 \mathrm{~cm} \mathrm{H} \mathrm{H}_{2} \mathrm{O} / 1 / \mathrm{sec}, \mathrm{p}>0.5$, total inspiratory work: $\overline{\mathrm{D}}=-10.4 \pm 76$ $\mathrm{g} \cdot \mathrm{cm}, \mathrm{p}>0.6$, elastive part of inspiratory work: $\mathrm{D}-3.9 \pm 13.5 \%, \mathrm{p}>0.3$ ).

Mean values found at different age periods, namely $2-35$ minutes, $60-150$ minutes and

* mean value \pm standard deviation. 
24 hours -7 days are given in Table II. Lung compliance corrected for body size differences was $0.79 \pm 0.07,1.15 \pm 0.3$ and $1.68 \pm 0.6 \mathrm{ml} / \mathrm{cmH}_{2} \mathrm{O} / \mathrm{kg}$ birth weight respectively. Only for lung compliance, there was a statistically significant difference $(p<0.001)$ between the means of these three age groups.

\section{FUNCTIONAL RESIDUAL CAPACITY (III)}

The functional residual capacity shows a gradual increase between the age of $1-2$ hours and 24 hours. In 6 infants who were followed from $1-2$ hours up to 24 hours of life, this increase was observed in each case and averaged $14- \pm 8 \mathrm{ml}$ (from 91 to 105 $\mathrm{ml}, \mathrm{p}<0.01$ ).

No significant change seems to occur between 24 hours and several days of age. FRC averaged $93 \pm 18.5 \mathrm{ml}(\mathrm{n}=16$, range $69-$ $135 \mathrm{ml})$ at 24 hours and $82 \pm 21 \mathrm{ml}(\mathrm{n}=9$, range $54-103 \mathrm{ml}$ ) at the age $6-12$ days without a statistically significant difference $(0.05<\mathrm{p}<0.1)$ between the means.

Already during the first day of life, FRC and compliance (C) are highly correlated: FRC $(\mathrm{ml})=10.1 \mathrm{C}\left(\mathrm{ml} / \mathrm{cm} \mathrm{H} \mathrm{H}_{2} \mathrm{O}\right)+56.4$ $(\mathrm{n}=17$, SEE $(\mathrm{y})=16.1, \mathrm{r}=0.77, \mathrm{p}<0.01)$. The specific compliance (compliance/FRC) during the first day of life is $0.042 \pm 0.01$ $(\mathrm{n}=17)$, thus approaching already during the first day relations seen later in life.

\section{BLOOD GASES AND ACID-BASE BALANCE DURING THE FIRST WEEK (IV)}

There is hypoxemia, hypercapnea and both respiratory and non-respiratory (metabolic) acidosis at birth as reflected by umbilical
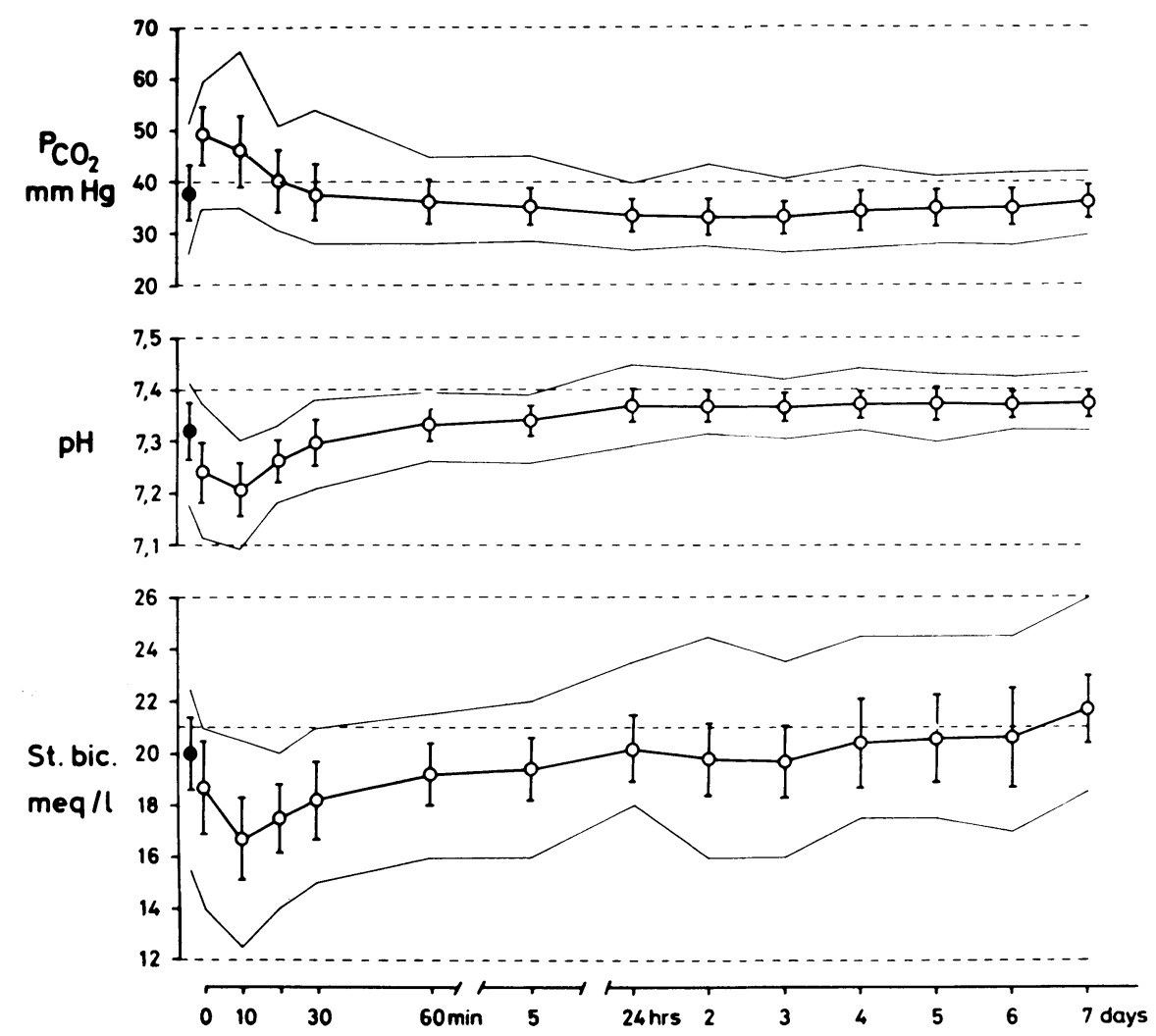

FIG. 2. Mean, standard deviation and range of arterial carbon dioxide tension, $\mathrm{pH}$ and standard bicarbonate at different ages during the first week of life (IV). Open circles (O): values in blood of the descending aorta (at time 0 in umbilical cord artery), filled circles $(\bullet)$ at time 0 values in blood of the umbilical cord vein. 
arterial blood (Fig. 2) with accumulation of lactic and pyruvic acid (IV). Acidosis and lactic acid concentration (Fig. 6) further increase during the first minutes following birth, but recede rapidly and steadily during the subsequent minutes and hours. Respiratory acidosis (hypercapnea) is abolished within 30 to 60 minutes after delivery, while $\mathrm{pH}$ exceeds 7.35 only after 24 hours of life; at the same time lactate and pyruvate values have approached adult resting values, while $\mathrm{P}_{\mathrm{CO}_{2}}$ is about $33 \mathrm{~mm} \mathrm{Hg}$. The adjustment of $\mathrm{pH}$ to normal adult values thus occurs in spite of persisting hypobasemia which is apparently counterbalanced by hyperventilation. Hypobasemia recedes significantly $(\mathrm{p}<0.001)$ during the rest of the first week of life and standard bicarbonate reaches the lower limit of the normal adult range by the 7 th day of life. This rise in standard bicarbonate is paralleled by a corresponding increase $(\mathrm{p}<0.001)$ in $\mathrm{P}_{\mathrm{CO}_{2}}$ from the age of $24-72$ hours untill 7 days (IV, Fig. 2). There are no significant differences in lactic acid concentration between 24 hours and 7 days $(1.0 \pm 0.15$ and $0.9 \pm 0.25 \mathrm{meq} / 1$ respectively, $\mathrm{p}>0.2$, IV).

Normal arterial saturation is on the average achieved by about 5 hours of life, by which time $\mathrm{PaO}_{2}$ is about $73 \mathrm{~mm} \mathrm{Hg}$ without any further significant change during the remainder of the first week of life (Fig. 3).

Oxygen capacity and hematocrit decrease slightly from the age of 5 and 24 hours respectively (Fig. 3).

The changes occurring in $\mathrm{pH}, \mathrm{PaCO}_{2}$, standard bicarbonate, $\mathrm{P}_{\mathrm{aO}_{2}}$ and $\mathrm{S}_{\mathrm{aO}_{2}}$ are significantly correlated to age and can be expressed as logarithmic functions of age (Table III) thus permitting prediction of normal values.
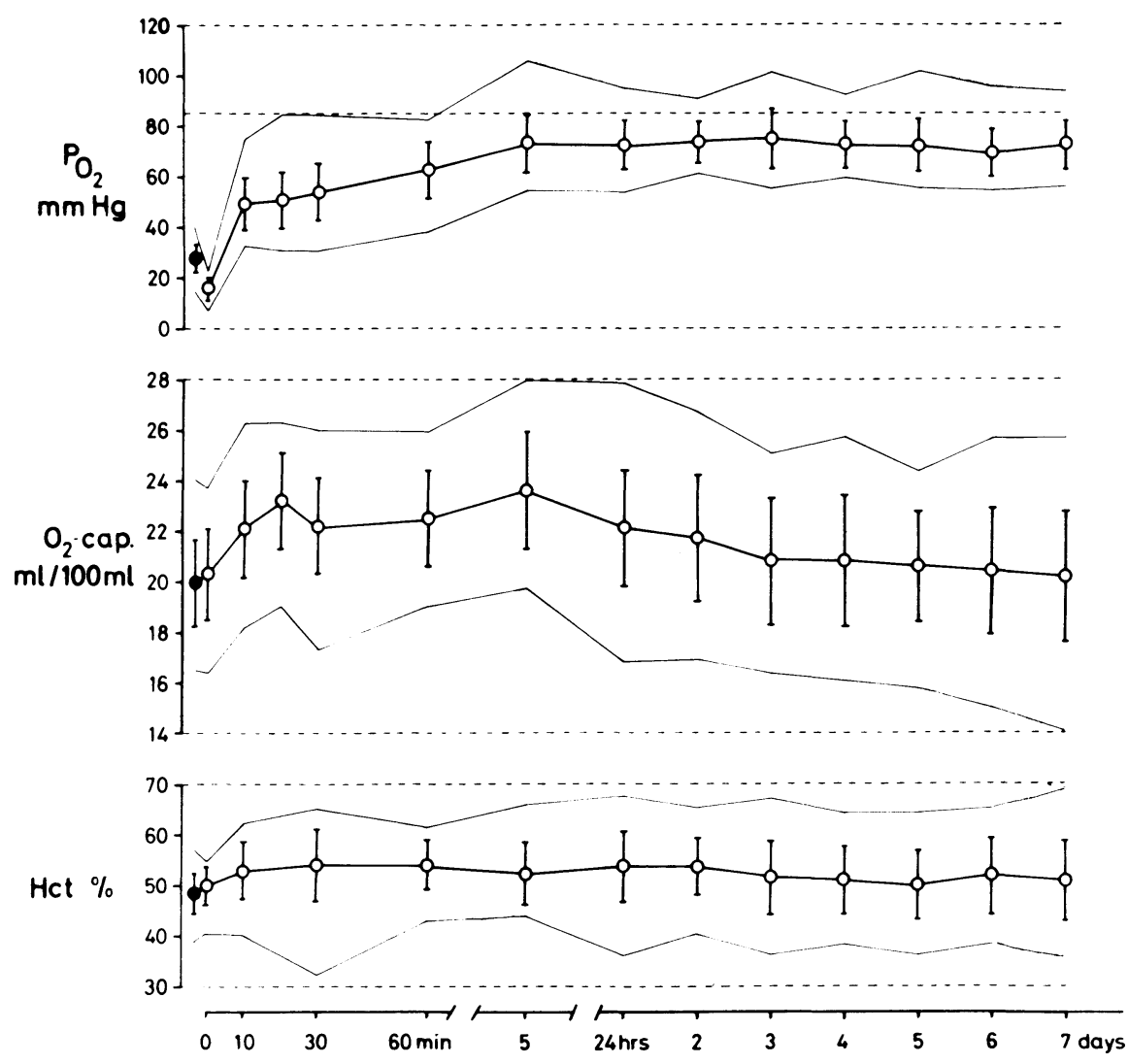

FIG. 3. Mean, standard deviation and range of arterial oxygen tension during air breathing, and of oxygen capacity and hematocrit in arterial blood at different ages during the first week of life (IV). Symbols as in Fig. 2. 
TABLE III.

Regression equations for $\mathrm{pH}, \mathrm{P}_{\mathrm{aCO}_{2}}$, standard bicarbonate, oxygen saturation and $\mathrm{P}_{\mathrm{aO}_{2}}$ during air breathing, and for $\mathrm{P}_{\mathrm{aO}_{2}}$, alveolar-arterial oxygen difference and anatomic shunt during oxygen $\left(\mathrm{F}_{\mathrm{IO}_{2}}=1\right)$ breathing as logarithmic functions of age (independent variable).

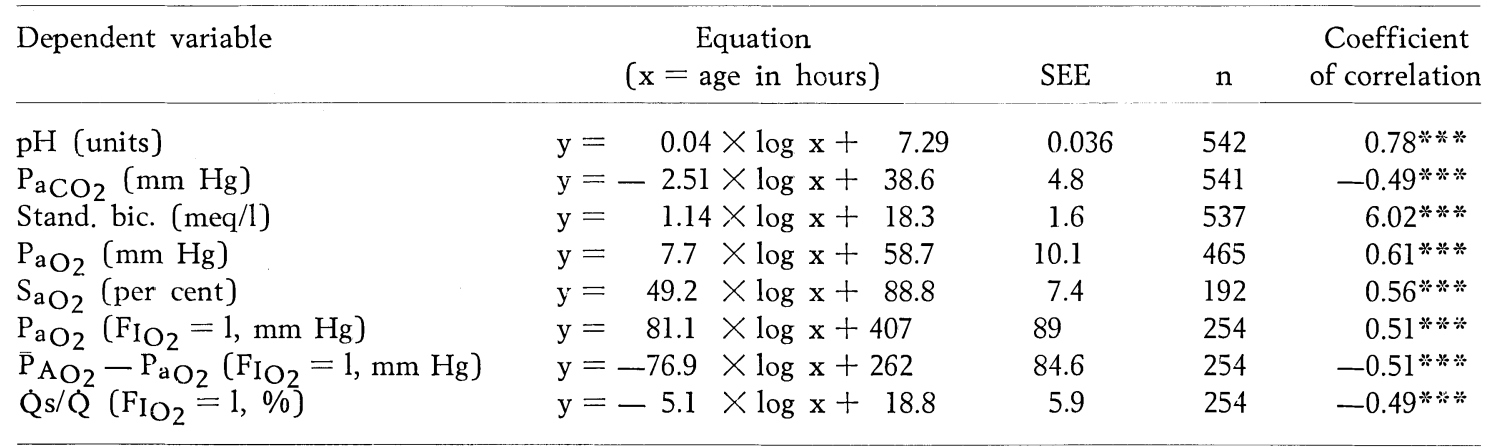

SEE $=$ standard error of estimate.

$* * *=p<0.001$.

VENOUS ADMIXTURE DUE TO TRUE ANATOMIC SHUNT DURING THE FIRST WEEK OF LIFE (V)

$\mathrm{P}_{\mathrm{aO}}$ during oxygen breathing averaged 309 $\mathrm{mm} \mathrm{Hg}$ with a wide range $(60-540 \mathrm{~mm}$ $\mathrm{Hg}$ ) at the age of 55 minutes, but showed a considerably higher mean level, between $527-589 \mathrm{~mm} \mathrm{Hg}$, from 5 hours to 7 days of age (Fig. 4).
The $\mathrm{PaO}_{2}$ of $60 \mathrm{mmHg}$ was the only value below $100 \mathrm{mmHg}$ observed in this series during oxygen breathing. In spite of this unusually low value the infant appeared normal judging from the clinical condition and from $\mathrm{pH}, \mathrm{PaCO}_{2}$, bicarbonate and lactate values. $\mathrm{PaO}_{2}$ during air breathing was $40 \mathrm{mmHg}$ at 60 minutes and $55 \mathrm{mmHg}$ at 5 hours of age, at which time $\mathrm{PaO}_{2}$ during oxygen breathing attained $4.97 \mathrm{mmHg}$.

Correspondingly, the average alveolar-arterial oxygen tension difference was highest
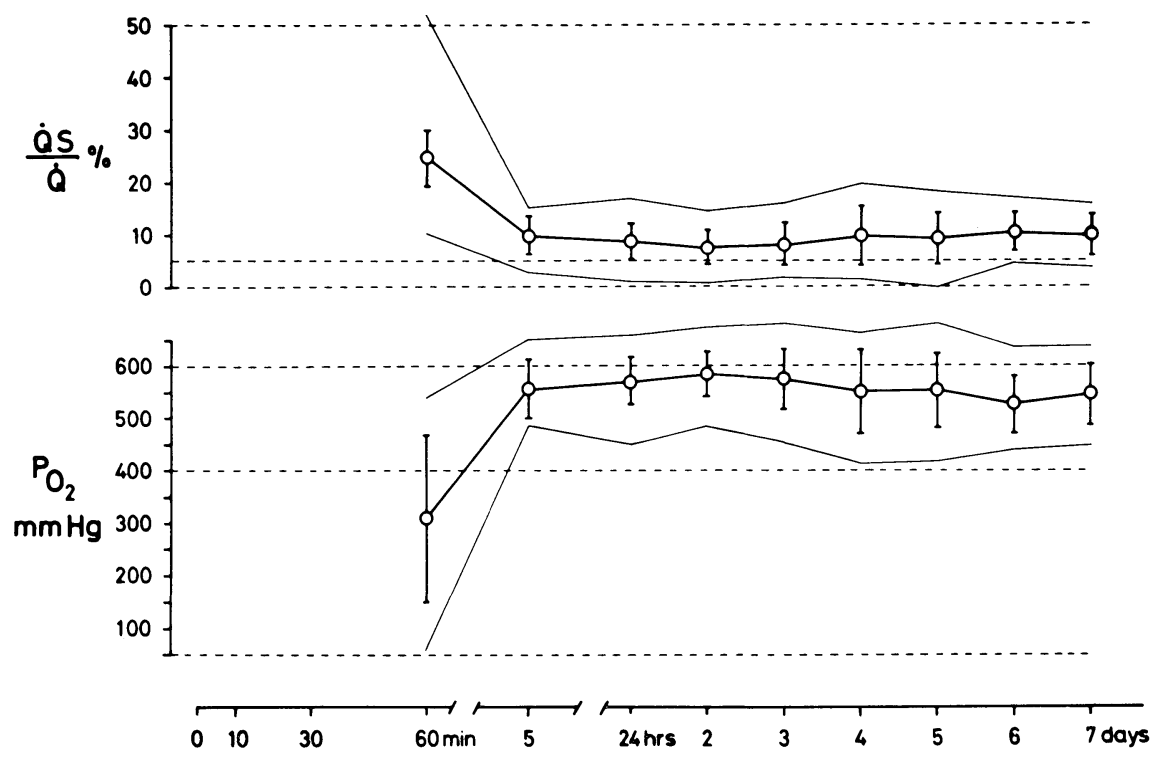

FIG. 4. Mean, standard deviation and range of arterial oxygen tension during oxygen breathing and calculated anatomic shunt at different ages during the first week of life (V). Symbols as in Fig. 2. 
at the age of 55 minutes averaging $356 \mathrm{~mm}$ $\mathrm{Hg}$; at the age of 5 hours to 7 days it averaged between 95 and $141 \mathrm{~mm} \mathrm{Hg}$.

Venous admixture due to anatomic shunt averaged 24 per cent of right ventricular output at the age of 55 minutes but decreased to an average between 7.6-10.9 per cent during the period 5 hours to 7 days, the lowest values being found at the age of 2 and 3 days (Fig. 4).

\section{STEADY STATE PULMONARY VENTILATION} AND DIFFUSING CAPACITY (VI)

Obstetrical data and individual data for most of the variables studied in connection with determination of DLCO at 24 hours and 7 days of life are given in the Appendix, Tables $1,2,3$. Table IV shows the mean values obtained at 24 hours and 7 days respectively as well as the mean differences.

Minute volume $\left(\mathrm{V}_{\mathrm{E}}\right)$, oxygen consumption $\left(\dot{V}_{2}\right)$, carbon dioxide elimination $\left(\dot{V}_{\mathrm{CO}_{2}}\right)$ and alveolar ventilation $\left(\mathrm{V}_{\mathrm{A}}\right)$ are statistically significantly correlated to body size. This held also for tidal volume ( $\mathrm{V}_{\mathrm{T}}$ ) when only cases with a regular breathing pattern were selectected (cf. VI).

Between 24 hours and 7 days of age, there was a slight decrease $(p<0.01)$ of the respiratory rate and the alveolar ventilation equivalent for $\mathrm{CO}_{2}\left(\dot{V}_{\mathrm{A}} / \dot{\mathrm{V}}_{\mathrm{CO}}\right)$ and increase $(\mathrm{p}<0.001)$ of the respiratory exchange ratio $(\mathrm{R})$. Minute volume $\left(\mathrm{V}_{\mathrm{E}}\right)$ decreased and heart rate increased slightly $(\mathrm{p}<0.05)$. Changes in tidal volume ( $\left.\mathrm{VT}_{\mathrm{T}}\right)$, oxygen consumption $\left(\mathrm{V}_{2}\right)$, ventilation equivalent for $\mathrm{O}_{2}\left(\dot{V}_{\mathrm{E}} / \mathrm{V}_{\mathrm{O}}\right)$, carbon dioxide elimination $\left(\dot{\mathrm{V}}_{\mathrm{CO}}\right)$, alveolar ventilation $\left(\dot{\mathrm{V}}_{\mathrm{A}}\right)$ and physiological dead space (VD) were slight and statistically not significant.

Both the physiological dead space/tidal volume ratio $\left(\mathrm{VD}_{\mathrm{D}} / \mathrm{V}_{\mathrm{T}}\right)$ and the diffusing capacity ( $\mathrm{DLCO}_{\mathrm{LCO}}$ ) decreased slightly from 24 hours to 7 days $(\mathrm{p}<0.05)$.

The ratio $\mathrm{V}_{\mathrm{D}} / \mathrm{V}_{\mathrm{T}}, \mathrm{D}_{\mathrm{LCO}}$ in relation to $\mathrm{V}_{\mathrm{A}}, \mathrm{V}_{\mathrm{O}_{2}}$ and body surfac area (BSA), and the alveolar - mean pulmonary capillary oxygen tension difference $\left(\overline{\mathrm{P}}_{\mathrm{AO}_{2}}-\overline{\mathrm{P}}_{\mathrm{CO}_{2}}\right)$, correspond to standard adult values.

\section{A-a $\mathrm{O}_{2}$ DIFFERENCE AND TOTAL VENOUS ADMIXTURE (VI)}

During air breathing $\mathrm{PaO}_{2}$ was on the average 72 and $74 \mathrm{~mm} \mathrm{Hg}$ at 24 hours and 7 days of life, and the $\overline{\mathrm{P}}_{\mathrm{AO}_{2}}-\mathrm{PaO}_{2}$ difference 31 and $30 \mathrm{mmHg}$ corresponding to a total venous admixture during air breathing of $20.9 \pm 6$ and $18.4 \pm 5.9$ per cent of right ventricular output respectively $(\mathrm{p}<0.05)$.

\section{CARDIAC OUTPUT AND OVERALL VENTILATION/PERFUSION RATIO (VI)}

Calculated from the assumed value of 3.5 $\mathrm{ml} / 100 \mathrm{ml}$ for the arterial-mixed venous oxygen difference (cf. VI) and measured oxygen uptake, cardiac output averaged $699 \pm 112 \mathrm{ml}$ and $646 \pm 101 \mathrm{ml}$ at 24 hours and 7 days respectively. This slight change parallels the decrease of $\dot{\mathrm{V}}_{\mathrm{O}_{2}}$ from 24 hours to 7 days.

The overall ventilation/perfusion ratio $\left(V_{A} / Q\right)$ estimated from these values for $Q$ and the corresponding measured values for $v_{\text {A }}$ averaged 0.63 and 0.66 at 24 hours and 7 days $(0.05<\mathrm{p}<0.1)$. 
TABLE IV.

Means (M), standard deviation (SD) and range of some data obtained for ventilation, intrapulmonary gas exchange and acid-base balance at the age of 24 hours and 7 days and differences (D) between means (VI).

24 hours

$\mathrm{n}$

S D range

\section{Temperature and heart rate}

$\left.\begin{array}{l}\overline{\mathrm{P}} \mathrm{AO}_{2}-\mathrm{P}_{\mathrm{aO}_{2}}, \mathrm{~mm} \mathrm{Hg} \\ \mathrm{Q} \text { s/Q anat., } \%\end{array}\right\} 100 \% \mathrm{O}_{2} \ldots \ldots$

Ventilation/perfusion ratio
Rectal temp., $\mathrm{C}^{\circ} \ldots \ldots \ldots \ldots \ldots \ldots \ldots$

Heart rate $\ldots \ldots \ldots \ldots \ldots \ldots \ldots \ldots \ldots \ldots$

\section{Ventilation}

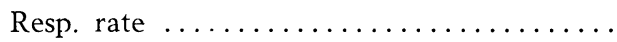

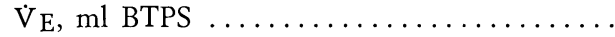

$\mathrm{V}_{\mathrm{T}}, \mathrm{ml}$ B'TPS $\ldots \ldots \ldots \ldots \ldots \ldots \ldots \ldots \ldots \ldots$

$\mathrm{V}_{\mathrm{O}_{2}}, \mathrm{ml}$ STPD $\ldots \ldots \ldots \ldots \ldots \ldots \ldots \ldots$

$\dot{\mathrm{V}}_{\mathrm{E}} / \mathrm{V}_{\mathrm{O}_{2}} \ldots \ldots \ldots \ldots \ldots \ldots \ldots \ldots \ldots \ldots$

$\dot{\mathrm{V}}_{\mathrm{CO}_{2}}, \mathrm{ml} \mathrm{STPD} \ldots \ldots \ldots \ldots \ldots \ldots \ldots$

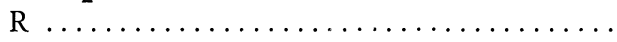

$\mathrm{P}_{\mathrm{aCO}_{2}}, \mathrm{~mm} \mathrm{Hg} \ldots \ldots \ldots \ldots \ldots \ldots \ldots$

$\dot{\mathrm{V}}_{\mathrm{A}}, \mathrm{ml}$ BTPS $\ldots \ldots \ldots \ldots \ldots \ldots \ldots \ldots \ldots \ldots$

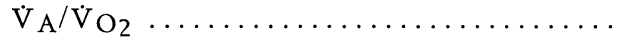

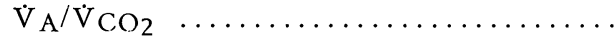

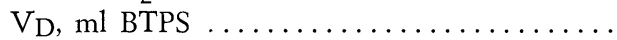

$\mathrm{V}_{\mathrm{D}} / \mathrm{V}_{\mathrm{T}} \ldots \ldots \ldots \ldots \ldots \ldots \ldots \ldots \ldots \ldots$

\section{Diffusion}

$\overline{\mathrm{P}}_{\mathrm{AO}_{2}}, \mathrm{~mm} \mathrm{Hg} \ldots \ldots \ldots \ldots \ldots \ldots \ldots \ldots$

$\mathrm{D}_{\mathrm{LCO}}, \mathrm{ml} / \mathrm{min} / \mathrm{mm} \mathrm{Hg} \ldots \ldots \ldots \ldots \ldots \ldots$

$\mathrm{D}_{\mathrm{L}_{2}}, \mathrm{ml} / \mathrm{min} / \mathrm{mm} \mathrm{Hg} \ldots \ldots \ldots \ldots \ldots \ldots$

$\overline{\mathrm{P}}_{\mathrm{AO}_{2}}-\overline{\mathrm{P}}_{\mathrm{CO}_{2}}, \mathrm{~mm} \mathrm{Hg}$

\section{Venous admixture}

$\mathrm{P}_{\mathrm{aO}}, \mathrm{mm} \mathrm{Hg}$

$\left.\begin{array}{l}\mathrm{P}_{\mathrm{AO}_{2}}-\mathrm{P}_{\mathrm{aO}}{ }_{2}, \mathrm{~mm} \mathrm{Hg} \text { tot., } \% \\ \mathrm{Q} / \mathrm{Q}\end{array}\right\}$ air $\ldots \ldots \ldots \ldots \ldots$

$\left.\mathrm{P}_{\mathrm{P}_{2}}, \mathrm{~mm} \mathrm{Hg}, \mathrm{mm} \mathrm{Hg}\right\} 100 \% \mathrm{O}_{2} \ldots \ldots$.

(Q́s/Q anat./Qs/Q tot.) • 100, \% $\ldots \ldots \ldots$

$100 \times \dot{\mathrm{V}}_{2} / 3.5 \approx \mathrm{Q}, \mathrm{ml} \ldots \ldots \ldots \ldots \ldots$.

$\dot{\mathrm{V}}_{\mathrm{A}} / \mathrm{Q}$

23

27

33

33

33

33

33

33

33

33

33

33

33

33

33

33

26

26

26

Acid-base balance etc.

St. bic., meq $/ 1$

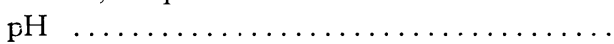

$\mathrm{Hb}, \mathrm{g} / 100 \mathrm{ml}$

Hct, per cent $\ldots \ldots \ldots \ldots \ldots \ldots \ldots \ldots \ldots$

$\mathrm{S} \mathrm{COHb}$ endogeneous, $\%$

$\mathrm{S} \mathrm{COHb}$ at examination, $\%$
36.5

117

$$
44
$$$$
703
$$

16.5

24.5

28.9

17.3

0.71

34.7

442

18.2

25.6

4.3

0.26

103

2.2

2.7

9.4

\section{2}

31

20.9

566

117

9.3

43.3

699

0.63

20.2

7.35

16.3

55.8

0.9

2.7

0.4
10

\section{9}

120

3.1

3.9

3.2

2.7

0.05

2.9

73

2.2

2.4

1.3

0.05

5.5

0.5

0.6

2.6

\section{7}

9

6.0

51

50

3.5

16.1

112

0.07

1.3

0.02

1.6

7.4

0.3

0.7
$35.5-37.2$

$88-137$

$27-79$
$388-975$
$10.0-22.7$
$13.9-34.7$
$21.9-36.9$
$10.0-22.8$
$0.60-0.83$
$29.8-41.0$
$243-580$
$13.3-22.9$
$21.7-30.3$
$2.5-7.5$
$0.17-0.38$

$89-114$

$1.2-3.1$

$1.5-3.8$

$4-15$

$$
\begin{gathered}
62-91 \\
11-46 \\
7.9-29.2 \\
450-665 \\
12-231 \\
3.0-17.0 \\
22.6-79.3
\end{gathered}
$$

$397-991$

$0.5-0.8$ 


\begin{tabular}{|c|c|c|c|c|c|c|c|c|}
\hline \multirow[b]{2}{*}{$\mathrm{n}$} & \multicolumn{3}{|c|}{7 days } & \multicolumn{4}{|c|}{7 days -24 hours } & \multirow[b]{2}{*}{$\mathrm{D} \%$} \\
\hline & M & S D & range & $\mathrm{n}$ & $\mathrm{D}$ & & $\mathrm{v}$ & \\
\hline 20 & 36.5 & 0.2 & $36.2-36.9$ & 20 & 0.05 & & 0.8 & 0.1 \\
\hline 24 & 123 & 12 & $108-161$ & 24 & 7 & $*$ & 8.7 & 6 \\
\hline 29 & 39 & 8 & $29-54$ & 29 & -5 & $* *$ & 16.0 & -11.4 \\
\hline 29 & 632 & 113 & $445-863$ & 29 & -52 & $*$ & 14.8 & -7.6 \\
\hline 29 & 16.6 & 2.5 & $9.6-21.4$ & 29 & 0.4 & & 14.7 & 2.5 \\
\hline 29 & 22.6 & 3.5 & $15.5-29.6$ & 29 & -1.5 & & 16.0 & -6.2 \\
\hline 29 & 28.0 & 3.2 & $22.6-37.1$ & 29 & -0.5 & & 9.8 & -1.8 \\
\hline 29 & 17.6 & 2.8 & $12.3-22.4$ & 29 & 0.7 & & 14.9 & 4.1 \\
\hline 29 & 0.78 & 0.25 & $0.68-0.90$ & 29 & 0.07 & $7 * * *$ & 7.7 & 10 \\
\hline 29 & 36.7 & 3.0 & $30.1-42.3$ & 29 & 1.8 & $* *$ & 6.2 & 5.1 \\
\hline 29 & 425 & 74 & $269-569$ & 29 & -3 & & 13.5 & -0.7 \\
\hline 29 & 18.8 & 1.8 & $16.2-22.6$ & 29 & 0.9 & & 10.3 & 5 \\
\hline 29 & 24.2 & 2.0 & $21.4-29.1$ & 29 & -1.3 & $\because * *$ & 6.3 & -5 \\
\hline 29 & 3.9 & 1.0 & $1.7-6.4$ & 29 & -0.3 & & 25.3 & -7.1 \\
\hline 29 & 0.24 & 0.05 & $0.17-0.36$ & 29 & -0.03 & & 16.8 & -11.5 \\
\hline 29 & 103 & 3.8 & $96-111$ & 29 & 1 & & 3.9 & 1 \\
\hline 25 & 2.0 & 0.5 & $1.2-2.9$ & 23 & -0.2 & $*$ & 15.5 & -9 \\
\hline 25 & 2.5 & 0.6 & $1.5-3.6$ & 23 & -0.3 & * & 15.5 & -9 \\
\hline 25 & 10 & 3 & $5-15$ & 23 & 0.6 & & 18.8 & 6.5 \\
\hline 29 & 74 & 7 & $62-91$ & 29 & 2 & $*$ & 5.0 & 2.8 \\
\hline 29 & 30 & 7 & $11-43$ & 29 & -1 & & 16.9 & -3.3 \\
\hline 29 & 18.4 & 5.9 & $5.9-29.4$ & 29 & -2.6 & $*$ & 18.6 & -13.3 \\
\hline 24 & 551 & 61 & $429-638$ & 24 & -14 & & 5.6 & -2.5 \\
\hline 24 & 122 & 57.5 & $50-252$ & 24 & 5 & & 24.1 & 4.3 \\
\hline 24 & 9.7 & 4.3 & $4.1-18.3$ & 24 & 0.4 & & 23.1 & 4.3 \\
\hline 23 & 58.7 & 22.1 & $23.7-98.8$ & 23 & 15.6 & $* *$ & 16.3 & 36 \\
\hline 29 & 646 & 101 & $443-846$ & 29 & -43 & & 16.0 & -6.2 \\
\hline 29 & 0.66 & 0.06 & $0.57-0.79$ & 29 & 0.03 & & 10.3 & 4.8 \\
\hline 29 & 21.8 & 1.5 & $19.5-25.0$ & 29 & 1.8 & $* * *$ & 6.0 & 9.0 \\
\hline 29 & 7.35 & 0.03 & $7.30-7.40$ & 29 & 0.01 & & & 0.1 \\
\hline 29 & 15.4 & 1.6 & $12.1-18.9$ & 29 & -1.0 & $* * *$ & 4.7 & -6.1 \\
\hline 27 & 51.1 & 7.1 & $35.8-65.8$ & 24 & -4.2 & $* * *$ & 6.6 & -7.6 \\
\hline 27 & 0.8 & 0.2 & $0.4-1.1$ & 26 & -0.2 & $* * *$ & 19.2 & -22.2 \\
\hline 29 & 2.5 & 0.8 & $1.2-4.9$ & 28 & -0.1 & & 23.8 & -3.7 \\
\hline
\end{tabular}




\section{DISCUSSION}

METHODS

The small size and the lack of cooperation of the subject to be studied make pulmonary function investigation in the newborn period difficult and limit its possibilities. The present series of studies as well as those of others (Cook et al., 1955; Stahlman, 1957; Nelson et al., 1962; Strang and McGrath, 1962; Prod'hom et al., 1964; and others), however, have demonstrated that suitable methods can be developed or adapted permitting investigation of the main mechanisms in respiratory function even in the youngest age group. If, in the present study (VI), in spite of the biological changes occurring, the serial examinations at 24 hours and 7 days of age (Table IV) are considered as duplicate determinations, then it appears that for most of the variables of particular importance for respiratory gas exchange, including alveolar ventilation and pulmonary diffusing capacity, a methodological reliability of the same order as in corresponding investigations in resting adults can be achieved.

\section{ONSET OF RESPIRATION AND INITIAL RESPIRATORY ADJUSTMENT}

Since, at initiation of extrauterine life, the fetus emerges from a watery environment into air, removal of lung liquid filling the alveolar spaces and upper airways is a prerequisite for successful aeration and gas exchange. In the mature fetal lamb the liquid contained in the lungs at term is in the order of $40--80 \mathrm{ml}$ which appears to be similar to that of the functional residual capacity of gas after initiation of breathing (Howatt et al., 1965). Similar figures ought to apply to the human fetus, the functional residual capacity has actually been shown to be of the same magnitude (III; Strang and McGrath, 1962; Prod'hom et al., 1964; Chu at al., 1964). Provided there is low surface tension in the lung after introduction of air the resting position of the lungs should thus be the same wether they contain liquid or air (Strang, 1967). Lung liquid can be drained, probably mostly from the upper airways, in considerable amounts during the delivery process, particularly during vaginal vertex delivery (Karlberg et al., 1962) leading to a more or less extensive air filling of the upper air passages prior to the first breath (III; Lind et al., 1964). Although water in the alveolar spaces themselves may be absorbed mainly into the pulmonary circulation (Potter, 1953) there is, at least in the newborn lamb, also evidence for removal of lung liquid through lymphatic channels in the pulmonary interstitial tissue (Boston et al., 1965). According to Strang (1967) the increase in lymph flow above the fetal level in the first two hours of ventilation could account for the removal of 30 per cent of the water and all the protein in the lung liquid.

The establishment of air liquid interfaces during the first breath generates surface ten- 
sions, the magnitude of which determines further aeration. The high "negative» pressures and high lung resistances regularly encountered during the first and of ten even the following breaths (I) reflect probably mainly cohesive surface tensions. According to Laplace's law surface tensions must be expected to diminish with increasing diameter of the air bubble in the alveoli partly filled with air and partly with liquid, i. e. with progressive removal of liquid and its replacement by air. It actually seems that the airfilled part of the alveolus takes the shape of an optimally-curved spherical bubble (Plank, 1967). Characteristically, in most of the infants in which the first breath showed a residual volume, the subsequent inspirations proceeded more easily judging from the slope of the inspiratory pressure volume curve.

During deflation, surface tension can be expected to exert a retractive pressure and can thus not account for the high positive pressures observed during expiration and the resulting square form of the respiratory loop. These are probably due to upper airway obstruction during the expiratory phase secondary to pharyngo-laryngeal closure (I).

With respect to the inspiratory part similar pressure volume curves as those obtained during the first breath and sometimes the following breaths have been observed in fetal lungs of the lamb when inflated with positive pressure (Strang, 1967). While the pressure magnitude and the slope of the inflation loop does not seem to differ significantly between mature and immature fetal lungs, during deflation, the latter retains less air at decreasing inflating pressures than the former and tends towards loosing all air when pressure returns to zero. A similar displacement of the deflation curve towards decreased volume has been found in lung preparations from infants succumbing to the Idiopathic Respiratory Distress Syndrome (IRDS) when compared with the lungs of newborn infants dieing from other than pulmonary causes, and was correlated to differences in the surface activity of lung extracts (Gribetz et al., 1959, Gruenwald et al., 1962). The low air-retaining capacity of the immature in relation to the mature lamb lung has also been ascribed to surface activity differences, namely higher surface tension in the alveoli of the immature lung. By generating higher lung retractive forces high surface tension would not only prompt alveolar collapse but might even tend to suck back liquid into the alveolus (Boston et al., 1965, Strang, 1967).

In accordance with these observations in mature fetal lamb lungs in most of the infants in whom the first breaths could be recorded, a residual volume was established during the first or, more seldom, during one of the following breaths as shown from a smaller deflation in relation to inflation volume. In some cases, however, such a residual volume was not observed; this could signify 1) that replacement of lung liquid by air occurs at a slower rate, or 2) that "normal" liquid replacement persists after expiration but the resting position of the lungs changes tending to diminish thoracic volume, or 3) that some aeration has occurred before the first breaths. Cineradiological examination of the onset of respiration (III) shows, in agreement with the different types of initation of respiration as shown by the analysis of the volume pressure relationship (I), that initial aeration can proceed more or less "easily" and rapidly, but complete disappearance of air from the lung fields after the first expiration was not observed. While aeration of the upper airways may occur prior to the first breath (III, Lind et al., 1964) there is no evidence that significant aeration of alveolar spaces may occur at this stage.

While it thus appears that even in the normal infant variation in the mechanical properties at birth is large, no definite conclusions as to the causes of this variation can be drawn from the present study (I). It is tempting to speculate that there may 
be interindividual differences in lipoproteine surface activity and thus in surface tension even among normal term infants.

The great interindividual variability with respect to breathing pattern, respiratory rate and minute volume as well as to the mechanical properties persists during the first minutes; already at 3-10 minutes, however, a striking similarity of the respiratory loops approaching the pattern seen after some hours and days of life (II) demonstrates the rapidity with which lung structures accomodate for aeration.

As reflected by arterial blood gases $\left(\mathrm{P}_{\mathrm{aO}}\right.$, $\mathrm{P}_{\mathrm{aCO}_{2}} \mathrm{~J}$ the degree of alveolar aeration and of mechanical adjustment allows very rapidly for effective pulmonary ventilation and gas exchange. At 5 to 10 minutes after delivery, $\mathrm{P}_{\mathrm{aCO}}$ has already decreased to $46 \pm 7 \mathrm{~mm}$ $\mathrm{Hg}$ and $\mathrm{PaO}_{2}$ in the descending aorta has reached $50 \pm 10 \mathrm{~mm} \mathrm{Hg}$. Analysis focused on the very first minutes of postnatal development have shown that from about one to two minutes adjustment is effective enough to allow for increasing oxygenation and $\mathrm{CO}_{2}$ elimination as judged from arterial blood gases (Engström et al., 1966).

By 30-60 minutes of age lung function appears to be firmly established as judged from functional residual capacity, mechanical properties of the lung and gas exchange as revealed by arterial blood gases. Respiratory acidosis is on the average abolished at this time $\left(\mathrm{P}_{\mathrm{aCO}}=38 \pm 6 \mathrm{~mm} \mathrm{Hg}\right.$ at 30 minutes and $36 \pm 4 \mathrm{~mm} \mathrm{Hg}$ at 60 minutes of life), while a relative hypoxemia, both in terms of oxygen saturation of the hemoglobin and oxygen tension in descending aortic blood persists. The relatively low $\mathrm{P}_{\mathrm{aO}_{2}}$ compared to normal adult standards at this age has been shown to correspond to an increased alveolar-arterial $\mathrm{PO}_{2}$ difference (Prod'hom et al., 1964). The low $\mathrm{P}_{\mathrm{aO}}$ in spite of rather normal effective alveolar oxygen tension $\left(\mathrm{PAO}_{2}\right)$ at this age appears to be for the most part due to anatomic R-L-shunt, which probably occurs mainly through normal fetal pathways (foramen ovale and ductus arteriosus), and to a minor degree to ventilation/ perfusion inequality, i. e. low ventilation/perfusion ratio. According to Prod'hom et al. (1964) roughly $2 / 3$ of total venous admixture is due to anatomic shunt at the age of about 90 minutes. Estimations based on own figures of $\mathrm{P}_{\mathrm{aO}_{2}}$ in the descending aorta during air and oxygen breathing (V) suggest a similar figure, namely about 80 per cent of total venous admixture to be caused by anatomic shunt at the age of 55 minutes.

\section{FURTHER DEVELOPMENT OF PULMONARY MECHANICS AND LUNG VOLUME}

Within a few minutes after delivery, respiratory loops during quiet breathing have approached the shape seen later during the neonatal period. At this age (range 2-35 minutes) lung compliance is $2.7 \pm 0.9 \mathrm{ml} / \mathrm{cm}$ $\mathrm{H}_{2} \mathrm{O}$ and increases to $3.9 \pm 0.9 \mathrm{ml} / \mathrm{cm} \mathrm{H}_{2} \mathrm{O}$ at $1-2.5$ hours and $5.6 \pm 1.8 \mathrm{ml} / \mathrm{cm} \mathrm{H}_{2} \mathrm{O}$ at the age of $1-8$ days (Table II). This increase is statistically highly significant. On the other hand, there is no statistically significant difference between the compliance measured at 24 hours and 8 days respectively. The compliance values found after some hours of life (II, III) are in good agreement with the values obtained by means of an airfilled system for measurement of oesophageal pressure (Swyer et al., 1960; Chu et al., 1964) and different techniques for measuring volume changes (cf. Polgar 1967). The trend of changes in compliance occurring during the first day of life has been confirmed by Drorbaugh et al. (1963) and Chu et al. (1964). On the other hand, respiratory work is significantly higher than the values reported by Cook et al. (1957) and Swyer et al. (1960). This is apparently due to the significantly bigger tidal volumes obtained with the "reverse" plethysmograph technique following rebreathing. Our values concerning 
respiratory work are thus not representative for basal standards but rather to be considered as an index for the changes occurring. On the other hand, the elastive part of respiratory work corresponds fairly well with the values reported by the above mentioned authors.

FRC measured at $0.5-2$ hours, 24 hours and 3-12 days of age fall into the same range of magnitude, and there is no statistically significant difference between FRC values obtained at an age of 24 hours and 6-12 days respectively $(\mathrm{p}>0.1)$. If serial measurements in the same individuals between $1-2$ hours and 24 hours of age are compared, there is, however, a slight, yet statistically significant increase $(p<0.01)$ suggesting that the increase in compliance is parallelled by a similar yet proportionally smaller increase in FRC. As later in life, FRC and compliance are highly correlated $(\mathrm{r}=0.77)$ and specific compliance at the age $1-24$ hours is on the average $0.042 \pm 0.01$. If, however, measurements at $1-2$ and at 24 hours are treated separately, the specific compliance is shown to increase significantly $(\mathrm{p}<0.01)$ from $0.036 \pm 0.008$ to $0.05 \pm 0.01$ indicating that after the rapid accomodation occurring during the first minutes, true changes in the elastic properties of the neonatal lung continue. A similar increase of specific compliance during the first hours of life has been noted by Chu et al. (1964) using the plethysmographic method (DuBois et al., 1956) for determination of FRC, but not after 24 hours of life. They enumerate the following possible causes for this initial increase: (1) alterations in the elastic elements following repeated stretching, (2) loss of fluid from the lung during the first hours of postnatal life, (3) changes in the alveolar surface-active lining or (4) increase with age in the number of alveoli participating in respiration. Changes in elastic properties due to loss of interstitial fluid seems so far the most realistic explanation since it is actually based on experimental evidence of decreasing lung weight in relation to body weight during the first 5 hours (Boston et al., 1965).

The compliance/FRC ratio of $0.055 \pm 0.01$ found by Chu et al. (1964) after 24 hours ( $1-7$ days) agrees well with that found in the present study using the closed-circuit method for determination of FRC at 24 hours of age (III) as well as with adult standards. This suggests a striking similarity in the elastic properties of the "mechanically adapted" neonatal lung with that of the normal adult.

The FRC values found in the present study (III) are intermediate between those obtained by identical technique in a group of very early $(29.3 \pm 2.0 \mathrm{ml} / \mathrm{kg})$ and very late $(21.6$ $\pm 1.4 \mathrm{ml} / \mathrm{kg}$ ) clamped infants less than 6 hours of age (Oh et al., 1967). There is a good general agreement between the FRC measured with the He-method $(26.5 \pm 5.7$ $\mathrm{ml} / \mathrm{kg}$ birth weight: III), the plethysmographic technique $(29 \pm 7.0 \mathrm{ml} / \mathrm{kg}$ : Klaus et al., 1960; $27.8 \mathrm{ml} / \mathrm{kg}$ : Klaus et al., 1962; $33.8 \pm 7.3$ $\mathrm{ml} / \mathrm{kg}$ : Auld et al., 1963) and the opencircuit nitrogen-washout method ( $31.3 \pm 11.3$ $\mathrm{ml} / \mathrm{kg}$ : Nelson et al., $1963 \mathrm{a}$ ) in infants over 1 hour of age.

When measuring lung volume concurrently with the nitrogen-washout and the plethysmographic technique in the same individual, Nelson et al. (1963 a) found, however, significantly higher values in 10 out of 22 infants with the plethysmographic method. They concluded, since the $\mathrm{N}_{2}$ and the Hemethod measure the ventilated portion of the thoracic gas volume, i. e. true FRC, and the plethysmographic technique total thoracic gas volume, that some healthy infants may have significant amounts of trapped air, i. e. airway obstruction. This is a surprising finding in view of the rather even gas distribution shown in the newborn infant (Tooley et al., 1960; Strang and McGrath, 1962; Nelson et al., 1962 b). 
While lung compliance shows a steady increase during the first 24 hours of life, pulmonary resistance appears to be mainly unchanged after the age of $1-2$ hours (Table II), averaging $27 \mathrm{~cm} \mathrm{H} \mathrm{H}_{2} \mathrm{O} / 1 / \mathrm{sec}$. At 2-35 minutes of life, pulmonary resistance averaged $35 \pm 20 \mathrm{~cm} \mathrm{H} \mathrm{H}_{2} \mathrm{O} / 1 / \mathrm{sec}$, the difference between this value and the value found later is, however, statistically not significant. The values obtained after $1-2$ hours of life are in good agreement with those obtained at corresponding ages by using pneumotachygraph flow recording (Swyer et al., 1960: $26 \mathrm{~cm} \mathrm{H}_{2} \mathrm{O} / 1 / \mathrm{sec}$, Polgar and String, 1966: $34 \mathrm{~cm} \mathrm{H}_{2} \mathrm{O} / 1 / \mathrm{sec}$ ) or calculation of flow rate from volume recording by means of a body plethysmograph (Cook et al., 1957: $29 \mathrm{~cm}$ $\mathrm{H}_{2} \mathrm{O} / 1 /$ sec.

Recently, Polgar and collaborators succeeded in measuring even the subdivisions of pulmonary resistance: airway resistance and lung tissue resistance, in the newborn infant. They determined airway resistance by means of the total body plethysmograph technique (DuBois et al., 1956) and lung tissue resistance by the method of Marshall and DuBois (1956), substracting the airway resistance, measured plethysmographically, from the pulmonary resistance determined by directly plotting the resistive component of intraoesophageal pressure against airflow on an x-y oscillograph (Polgar and String, 1966). By substracting total pulmonary resistance measured when breathing through a plastic oral airway of known resistance, from the pulmonary resistance measured when breathing through the nose, even nasal resistance to breathing could be estimated (Polgar and Kong, 1965); this latter was found to be $12.1 \pm 5.5 \mathrm{~cm} \mathrm{H}_{2} \mathrm{O} / 1 / \mathrm{sec}(\mathrm{n}=5)$ or about 42 per cent of the total airway resistance against about 63 per cent in adults. However, total pulmonary resistance in this series was higher $\left(47.5 \mathrm{~cm} \mathrm{H} \mathrm{H}_{2} \mathrm{O} / 1 / \mathrm{sec}\right)$ than values reported by other investigators. When measured concurrently, total pulmonary resistance was
$34.1 \pm 8.9 \mathrm{~cm} \mathrm{H}_{2} \mathrm{O} / 1 / \mathrm{sec}$ and oral breathing airway resistance $25.4 \pm 6.4 \mathrm{~cm} \mathrm{H}_{2} \mathrm{O} / 1 / \mathrm{sec}$, yielding an average lung tissue resistance of $8.7 \pm 6 \mathrm{~cm} \mathrm{H}_{2} \mathrm{O} / 1 / \mathrm{sec}$ (Polgar and String, 1966); this corresponds to approximately 40 per cent of mean pulmonary resistance corrected for nasal resistance. Though the error involved in this type of study in the newborn infant is larger than in the adult, these results should indicate that total mean opposing resistive forces in relation to minute ventilation are lower in the newborn infant than in the adult (Polgar, 1967). This should mainly be due to lower nasal resistance, while oral airway resistance is similar, and tissue resistance somewhat higher in the newborn infant.

\section{"LATE» ADJUSTMENT OF INTRAPULMONARY GAS EXCHANGE}

After the rapid initial adaptative processes only minor changes occur during the remainder of the first week of life.

During the subsequent hours of extrauterine life, arterial oxygen saturation and oxygen tension continue to rise attaining by five hours of age $96 \pm 3$ per cent and $74 \pm 12$ $\mathrm{mm} \mathrm{Hg}$ respectively. During oxygen breathing, $\mathrm{PaO}_{2}$ rises to $555 \pm 56 \mathrm{~mm} \mathrm{Hg}$ corresponding to an alveolar-arterial $\mathrm{P}_{\mathrm{O}_{2}}$ difference of $124 \pm 54 \mathrm{~mm} \mathrm{Hg}$ and an anatomic shunt of $9.8 \pm 3.9$ per cent of cardiac output. As discussed above, these changes coincide with an important rise in lung compliance and probably some adjustment in FRC. In spite of further small adjustments in the lung's mechanical properties, oxygenation of arterial blood does not undergo any further changes of significance, and anatomic shunt appears to be mainly unchanged, with however, a minimum value at 2 days of age $(7.6 \pm 3.1$ per cent $)$. Thus, even after one week's "acclimatization" to extrauterine existence, the lung of the newborn infant has not yet attained the same efficiency for oxy- 
genation of arterial blood as that of the normal adult.

Theoretically, decreased arterial oxygen tension can be caused either by alveolar hypoventilation or by mechanisms increasing the alveolar-arterial oxygen tension difference. Three factors may contribute to the latter (VI): 1) The diffusion component which may give rise to a $\overline{\mathrm{P}}_{\mathrm{AO}}-\mathrm{P}_{\mathrm{C}^{\prime} \mathrm{O}_{2}}$ difference in the presence of impaired diffusion, but in the normal subject only under conditions of hypoxic ambient air, 2) the distribution component including both alveoli receiving an excess of perfusion (low ventilation/ perfusion ratio) and those receiving an excess of ventilation (high ventilation/perfusion ratio, i. e. large salveolar" dead space) and 3) the shunt component due to anatomic shunt, i. e. shunting of venous blood into the postpulmonary circulation thus establishing a $\overline{\mathrm{P}}_{\mathrm{c}}^{\prime} \mathrm{O}_{2}-\mathrm{P}_{\mathrm{aO}_{2}}$ difference.

Alveolar oxygen and carbon dioxide tensions (VI) exclude alveolar hypoventilation at least from the age of 24 hours, but similar alveolar gas tensions have been reported already at the age of 4 hours (Prod'hom et al., 1964) and are, at least in the normal infant, probably present even earlier as judged from arterial $\mathrm{P}_{\mathrm{CO} 2}$ (IV).

In view of the magnitude of $\mathrm{DLCO}_{\mathrm{LCO}}$ and the low $\overline{\mathrm{P}}_{\mathrm{AO}_{2}}-\overline{\mathrm{P}}_{\mathrm{CO}_{2}}$ difference observed in the present study the diffusion component does not appear to contribute substantially to the $\overline{\mathrm{P}}_{\mathrm{AO}_{2}}-\mathrm{PaO}_{2}$ difference at least during breathing of air and hyperoxic inspiratory gases.

Thus the alveolar-arterial $\mathrm{P}_{\mathrm{O}_{2}}$ difference of 31 and $30 \mathrm{~mm} \mathrm{Hg}$ during air breathing at 24 hours and 7 days, corresponding to a total venous admixture of on the average 20.9 and 18.4 per cent of the cardiac output $(\bar{D}=2.5, p<0.05)$ should be due to the effect of shunt and distribution component.

Since anatomic shunt determined during oxygen breathing was found to be $9.3 \pm 3.5$ and $9.7 \pm 4.3$ per cent of cardiac output res- pectively, it should account for approximately 43 and 59 per cent of total venous admixture at the age of 24 hours and 7 days respectively if one assumes that oxygen breathing does not change significantly neither blood flow through shunt channels nor the arterial mixed venous $\mathrm{O}_{2}$ difference (cf. V).

These results are conflicting with those from earlier reports (Nelson et al., $1963 \mathrm{~b}$, Prod'hom et al., 1964) concerning mainly slightly premature infants delivered by caesarean section, in which venous admixture, at least after 4 hours of age, was considered to be mainly due to true anatomic shunt. The main causes for this discrepancy appear to be methodological differences in measuring $\mathrm{P}_{\mathrm{O}_{2}}$ in blood with high oxygen tensions and the difference in gestational age of the infants studied and the type of their delivery (V).

As indicated by the low values of physiological dead space, alveolar dead space due to alveoli with high ventilation/perfusion ratio does not appear to be of any critical importance for gas exchange. This is in accordance with the findings of a very small arterialalveolar $\mathrm{P}_{\mathrm{CO}_{2}}$ difference (Nelson et al., 1962 b).

The contribution of the different components to the total alveolar-arterial oxygen tension difference can be shown to correspond to the following gas pressure gradients (Rahn and Farhi, 1962, Rahn and Farhi, 1964): alveolar dead space component to $\mathrm{PaCO}_{2}-$ $\overline{\mathrm{P}}_{\mathrm{ACO} 2}$, low ventilation/perfusion component to $\mathrm{P}_{\mathrm{aN}_{2}}-\overline{\mathrm{P}}_{\mathrm{AN}_{2}}$, and the anatomic shunt component to approximately $\left(\overline{\mathrm{P}}_{\mathrm{AO}_{2}}-\mathrm{P}_{\mathrm{aO}_{2}}\right)$ $-\left(\mathrm{P}_{\mathrm{aCO}_{2}}-\overline{\mathrm{P}}_{\mathrm{ACO}_{2}}\right)-\left(\mathrm{P}_{\mathrm{aN}_{2}}-\overline{\mathrm{P}}_{\mathrm{AN}_{2}}\right)$ $=\overline{\mathrm{P}}_{\mathrm{C}} \mathrm{O}_{2}-\mathrm{P}_{\mathrm{aO}_{2}}$ (VI). Although only $\mathrm{PO}_{2}$ differences have been determined in the present investigation (VI), these differences have been calculated from the mean values obtained at 24 hours and 7 days of age and have been collected in Fig. 5, and opposed to typical figures for normal adults in order to demonstrate the peculiarity of gas exchange in the newborn infant. 
The arterial-alveolar $\mathrm{P}_{\mathrm{N}_{2}}$ difference calculated on the basis of shunt estimations is in good agreement with the urinary-alveolar $\mathrm{PN}_{2}$ difference actually determined in the newborn infant (Rahn and Farhi, 1964). Since nitrogen is an inert gas its pressure in the urine is equal to that in the tissues and in the arterial and venous blood (cf. Rahn and Farhi, 1964).

It is noteworthy that the contribution of the low ventilation/perfusion distribution component decreased from about 57 per cent of total venous admixture at 24 hours to about 40 per cent at 7 days $(\mathrm{p}<0.01)$. This finding is in perfect agreement with the observation of a decreasing urinary-alveolar $\mathrm{P}_{2}$ difference in the newborn infant during the first 5 days of life (Rahn and Farhi, 1964).

A further reduction of the distribution component appears to occur during the following months of life. In the infant of some months of age, the distribution component has been estimated to account for only about 10 per cent of total venous admixture (Riegel, 1967).

Calculation of cardiac output from oxygen uptake and an arterial-mixed venous oxygen difference of $3.5 \mathrm{ml} / 100 \mathrm{ml}$ yields values in surprisingly good agreement with figures obtained by direct measurement (Gessner et al., 1965; Burnard et al., 1966; Arcilla et al., 1967). The overall pulmonary ventilation/ perfusion ratio calculated from $\dot{V}_{\mathrm{A}}$ and the
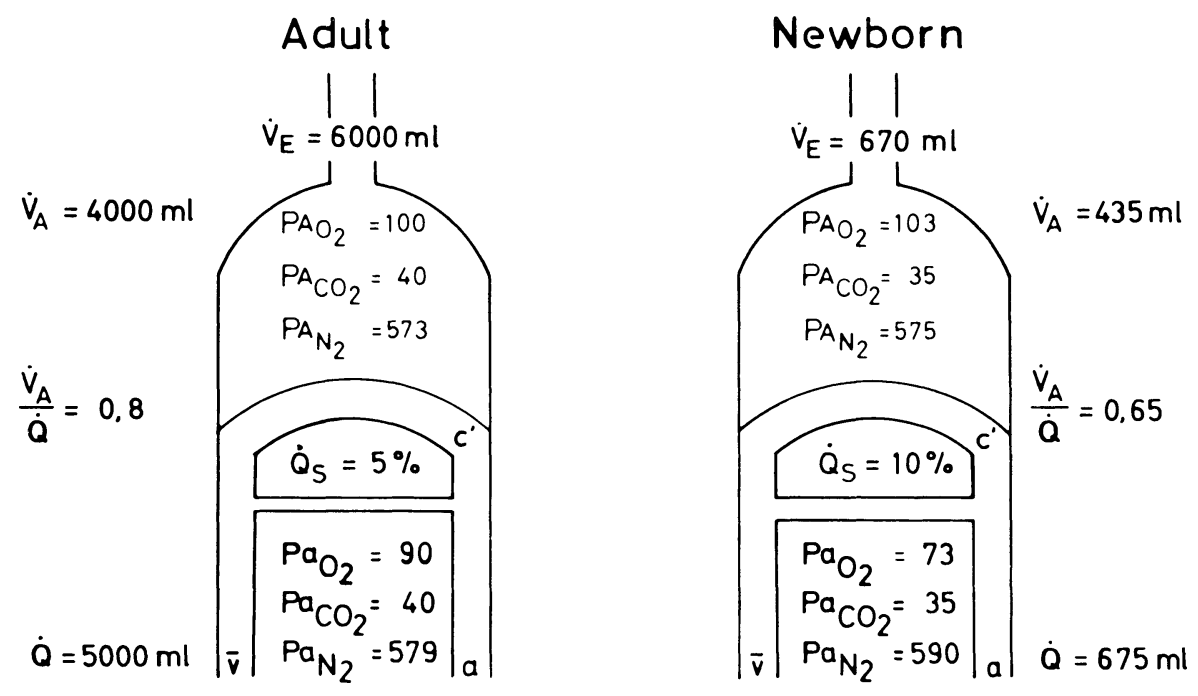

$$
\begin{aligned}
& 10 \mathrm{mmHg} \overline{P A}_{\mathrm{O}_{2}}-\mathrm{Pa}_{2} \quad 30 \mathrm{~mm} \mathrm{Hg} \\
& 10 \text { " } \mathrm{PA}_{2}-\overline{\mathrm{P}}_{\mathrm{O}_{2}} \quad 10 \text { ". } \\
& 0-1 . \mathrm{Pa}_{\mathrm{CO}_{2}}-\overline{\mathrm{PA}}_{\mathrm{CO}_{2}} \text { 0-2" } \\
& 6 \text { " } \mathrm{Pa}_{\mathrm{N}_{2}}-\bar{P}_{\mathrm{A}_{2}} \text { 10-15" } \\
& 4 \text { " } \bar{P}_{\mathrm{O}_{2}^{\prime}}^{\prime}-\mathrm{Pa}_{\mathrm{O}_{2}} \text { 15-20" }
\end{aligned}
$$

FIG. 5. Comparison between typical figures of respiratory exchange in the adult and the newborn infant after the first day of life (VI). 
corresponding values of estimated $\dot{Q}$, was 0.63 and 0.66 at 24 hours and 7 days respectively, and thus significantly lower than in adults. Even these figures suggest the presence of an important number of alveoli with low ventilation/perfusion ratio, which has been shown to account for part of the total venous admixture. The slight increase in overall $\mathrm{V}_{\mathrm{A}} / \mathrm{Q}$ between 24 hours and 7 days, though statistically not significant, is an accordance with the finding of a decreasing contribution of the distribution component to total venous admixture during the same age period.

\section{ACID-BASE BALANCE}

Composition of cord blood during delivery reflects the more or less pronounced disturbance of the functional relationship between mother and fetus during labour and delivery (James, 1965), but does not reflect the normal basal condition in utero. Great interindividual differences in the degree of this disturbance even in the course of the normal delivery obviously account for the wide variation of "normal» $\mathrm{P}_{\mathrm{O}_{2}}, \mathrm{P}_{\mathrm{CO}_{2}}, \mathrm{pH}$ and bicarbonate values reported in both arterial and venous cord blood (cf. Wulf, 1967; IV).

There are no figures available for human fetal blood gas and acid-base relations in the undisturbed basal state in utero. It is however well established (cf. IV) that there is maternal respiratory alkalosis during pregnancy secondary to hormone induced hyperventilation, compensated by hypobasemia which results in unchanged or slightly elevated $\mathrm{pH}$. Hyperventilation corresponds to a $\mathrm{PaCO}_{2}$ of about $30-32 \mathrm{~mm} \mathrm{Hg}$ and a decrease of standard bicarbonate by about $3 \mathrm{meq} / 1$, while $\mathrm{P}_{\mathrm{aO}}$ is within the normal range (IV).

With respect to the structure of the human placenta and its functional properties (Metcalfe, 1967, Wulf, 1967) it seems reasonable to assume a $\mathrm{P}_{\mathrm{CO}_{2}}$ for umbilical venous blood during intrauterine steady state conditions only a few $\mathrm{mm} \mathrm{Hg}$ higher than the maternal arterial $\mathrm{P}_{\mathrm{CO}_{2}}$ since the composition of the intervillous capillary space blood must lie between that of maternal arterial and uterine venous blood and $\mathrm{P}_{\mathrm{CO}_{2}}$ is likely to be lower than the $38 \mathrm{~mm} \mathrm{Hg}$ found in umbilical venous blood at the end of the delivery process (IV).

This value is admittedly somewhat lower than the umbilical venous $\mathrm{P}_{\mathrm{CO}_{2}}$ values reported in most of the previous studies (cf. Wulf, 1967) but it is in perfect agreement with that found by Engström et al. (1966) which is probably due to the fact that in these two studies analyses were performed shortly after blood sampling.

On the other hand, an important $\mathrm{PO}_{2}$ gradient must be expected through the placental barrier because of the oxygen consumption of the placenta itself, which must be significant at least near term (Dawes, 1965), and veno-arterial shunts which seem to be present on both sides of the barrier (Metcalfe, 1967; Wulf, 1967). According to Dawes (1965) reasonable figures would be 20 to $30 \mathrm{~mm} \mathrm{Hg}$ for umbilical arterial and 40 to $50 \mathrm{~mm} \mathrm{Hg}$ for umbilical venous $\mathrm{PO}_{2}$ which would cover the observations on different species and also the upper limits of the figures reported for human cord blood during or immediately after delivery.

While it thus appears that the fetus in utero is living in a state of slight hypocapnea and decreased oxygen tension according to adult standards and, as judged from umbilical venous $\mathrm{pH}$ at birth and from resting maternal lactate values (Derom, 1964), if ever, only in a slightly acidotic environment, the delivery process induces more or less pronounced respiratory and metabolic acidosis due to $\mathrm{CO}_{2}$ retention and accumulation of fixed acids along with hypoxemia which increase postnatally until a maximum is reached at about 1-2 minutes (Engström et al., 1966; IV). Subsequent recovery from the acidotic state at birth is primarily achieved by pulmonary elimination of carbon dioxide while recession of true metabolic acidosis as judged from lactate concentrations will take several hours up to one day (IV, Fig. 6). This adjustment 


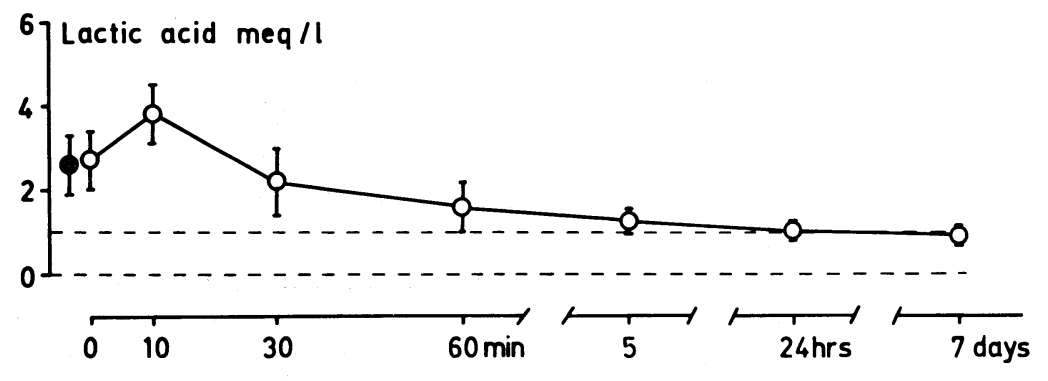

FIG. 6. Mean and standard deviation of arterial lactic acid concentration at different ages during the first week of life (IV). Symbols as in Fig. 2. leads at 24 hours of life to a pattern of acidbase status very similar to that of the mother prior to labour, i.e. a hypocapnea corresponding to a $\mathrm{PaCO}_{2}$ of about $33 \mathrm{~mm} \mathrm{Hg}$, a hypobasemia corresponding to a standard bicarbonate concentration of about $20 \mathrm{meq} / 1$ and a bicarbonate ion concentration of about $19 \mathrm{meq} / \mathrm{l}$, and with a $\mathrm{pH}$ slightly beneath 7.4. During the further course of the first week $\mathrm{P}_{\mathrm{aCO}}$ increases towards normal adult standards paralleled by an increase in bicarbonate concentration with mainly unchanged lactate levels (Fig. 6).

The behavior of $\mathrm{P}_{\mathrm{CO}_{2}}$, bicarbonate and lactate suggests that in the normal newborn infant after the age of 24 hours, there is, if any, only insignificant "true metabolic acidosis", i. e. accumulation of fixed acids. In accordance with conditions in the pregnant woman it rather appears that after the age of 24 hours, hyperventilation is the primary change which is counterbalanced by a secondary hypobasemia. The cause for this hyperventilation in relation to the metabolic rate is not obvious. It may be due to a "presetting" of the infant's respiratory center to values to which it had probably been exposed in utero, or to a sensibilization of the respiratory center by similar mechanisms as those acting in adult man during altitude acclimatization. Carbon dioxide sensitivity curves in the newborn actually show a similar decrease of carbon dioxide stimulation threshold (Avery et al., 1963) as in pregnant women, and in altitude adapted subjects (Kellogg, 1963) during their altitude sojourn as well as after return to sea level. Though subjected to great interindividual variations the main part of reduction of the increased ventilation after return from altitude to sea level appears to occur on the average during the period of approximately one week (cf. IV) which agrees quite well with the observed changes in the newborn infant.

There is evidence that the normal $\mathrm{P}_{\mathrm{aO}_{2}}$ in resting subjects breathing air at sea level is low enough to constitute a mild ventilatory stimulation, but becomes effective only when the individual is sensitized to lower $\mathrm{P}_{\mathrm{aCO}}$ (Kellogg, 1963). Since there is only a weak, yet statistically significant, correlation between $\mathrm{P}_{\mathrm{aCO}_{2}}$ and $\mathrm{P}_{\mathrm{aO}_{2}}$ during the first week of life, it is, however, improbable that a chemoreceptor drive plays a major role in the origin of neonatal hyperventilation. 


\section{SUMMARY}

During gestation the placenta subserves the external respiration of the fetus as well as its metabolism. With the initiation of extrauterine life the placental circulation is eliminated and the fetus emerges from a watery environment into air. This implies the establishment of a new autonomic function, that of pulmonary respiration, which process is intimately linked to a profound readjustment of the circulation.

The present series of investigations has been performed to elucidate certain of the processes involved in pulmonary gas exchange and to evaluate its efficiency compared to adult standards during the period of adjustment to extrauterine life. Though the most important and rapid changes in this adaptative process occur during the first seconds and minutes of extrauterine life they continue far beyond this period. Observations have therefore been extended until the end of the neonatal period defined as the first week of life; this has been considered particularly important as information as to the later period of this adjustment is scarce or lacking. Emphasis is laid on development of function.

Because of the significant morbidity and mortality of the newborn infant in disorders of respiration all investigations throwing more light on the normal respiratory mechanisms and their alterations in disease have important practical implications by improving diagnostic possibilities and facilitating objective evaluation of therapeutic measures.

A total of 172 healthy fullterm infants born after an uneventful pregnancy of normal length and uncomplicated vertex delivery are the subjects of the different studies.

The size of the subjects to be studied and the lack of cooperation posed special methodological problems. Suitable procedures and methods permitting reproducible and valid measurements have been developed or adapted for the study of mechanics of breathing, functional residual capacity, pulmonary ventilation, diffusing capacity and gas exchange. Since capillary $\mathrm{P}_{\mathrm{O}_{2}}$ does not accurately reflect arterial $\mathrm{P}_{\mathrm{O}_{2}}$ a safe procedure permitting arterial blood sampling without disturbing steady state conditions had to be developed.

The onset of respiration and initial aeration of the lungs is characterized by the generation of very high resistive forces, probably mainly due to high surface tension. Subsequently, lung compliance increases while lung resistance and inspiratory work decrease, the speed of these changes being highest in the beginning and slowing down subsequently.

Within one hour after delivery, the functional residual capacity amounts to $40-80$ $\mathrm{ml}$ and shows a relation to lung compliance similar to that later in life. Changes after 24 hours of life are insignificant.

There is hypoxemia, $\mathrm{CO}_{2}$ retention and accumulation of fixed acids, i. e. respiratory and metabolic acidosis at birth. The respira- 
tory component of acidosis is on the average abolished at 30 minutes and metabolic acidosis at 24 hours of life. $\mathrm{P}_{\mathrm{CO}}$ attains a minimum of about $33 \mathrm{~mm} \mathrm{Hg}$ at 24 hours of life and increases slightly to $36 \mathrm{~mm} \mathrm{Hg}$ at 7 days. This hyperventilation appears to be counterbalanced by a corresponding hypobasemia which recedes during the subsequent days. following closely the increase of $\mathrm{PCO}_{2}$. This regulation shows a striking similarity with the changes occurring during and after adaptation to altitude.

Arterial oxygen tension during air breathing increases within 5 hours to, on the average, about $73 \mathrm{mmHg}$, after which time no further significant changes occur. Arterial oxygen tension is thus significantly lower than in normal adults.

Arterial oxygen tension during oxygen breathing averages $309 \mathrm{mmHg}$ at 55 minutes of life and between 527 and $589 \mathrm{mmHg}$ during the period between 5 hours and 7 days of life, corresponding to an anatomic $\mathrm{R}-\mathrm{L}$ shunt of about 24 and between 7.6 and 10.9 per cent of cardic output respectively.

Among the different variables studied in connection with the determination of diffusing capacity during steady state conditions at the age of 24 hours and 7 days, only the following variables show a statistically significant change during this period: heart rate, respiratory rate, minute ventilation $\left(\dot{V}_{E}\right)$, the alveolar ventilation/carbon dioxide elimination ratio $\left(\mathrm{V}_{\mathrm{A}} / \mathrm{V}_{\mathrm{CO}}\right)$, the respiratory exchange ratio $(\mathrm{R})$, the dead space/tidal volume ratio $\left(V_{D} / V_{T}\right)$, the pulmonary diffusing capacity for $\mathrm{CO}$, the total venous admixture, the anatomic shunt/total venous admixture ratio.

Alveolar ventilation in relation to oxygen consumption, physiological dead space in relation to tidal volume, the pulmonary diffusing capacity for $\mathrm{CO}$ in relation to oxygen consumption, alveolar ventilation and body surface area, and the alveolar - mean pulmonary end capillary oxygen tension difference are of the same order as in healthy resting adults.

The alveolar-arterial oxygen tension difference is in the order of $30 \mathrm{~mm} \mathrm{Hg}$ and mainly unchanged during the age of 24 hours and 7 days. It is thus significantly higher than in healthy adults. Both anatomic shunt and ventilation/perfusion inequality, i.e. alveoli with low ventilation/perfusion ratio account for this difference. After the initial adaptation, the contribution from ventilation/perfusion inequality decreases during the first week of life.

In accordance with these findings, the overall ventilation/perfusion ratio was estimated to be on the average about 0.65 with a slight tendency to increase between 24 hours and 7 days.

The changes of most of the variables followed continuously from birth to 7 days can be expressed as a logarithmic function of age showing that the adaptative changes proceed most rapidly in the initial stage.

Even at the age of 7 days the lung of the newly born infant has not yet attained the same efficiency with respect to oxygen exchange as that of the healthy adult. 


\section{RÉSUMÉ}

Durant la gestation, le placenta subvient à la respiration du foetus aussi bien qu'à son métabolisme. C'est avec le début de la vie extra-utérine que la circulation placentaire est supprimée et que le foetus surgit à l'air quittant un mileu aqueux. Ceci implique, d'urgence, l'établissement d'une nouvelle fonction autonome, celle de la respiration pulmonaire. Ce processus est intimement lié à une profonde réadaptation de la circulation.

Les présentes séries de recherches ont eu pour but d'éclaircir quelques-uns des processus mis en jeu dans l'échange gazeux pulmonaire et d'évaluer leur efficacité comparée à la norme chez l'adulte, durant la période de l'adaptation à la vie extra-utérine. Bien que les changements les plus rapides et les plus importants de cette adaptation se réalisent pendant les premières secondes et minutes de la vie extra-utérine, ils se prolongent audelà de cette période. On a donc continué les observations jusqu'à la fin de la période néonatale, la première semaine de vie par définition. On a considéré cela comme d'autant plus important que les informations sur la période tardive de l'adaptation sont rares ou inexistantes. Le point a été mis sur le développement de la fonction respiratoire.

Le taux tojours considérable de la mortalité néo-natale est en grande partie attribuable aux difficultés de l'adaptation de l'hématose à la naissance. En améliorant les possibilités de diagnostic et d'évaluation des moyens thérapeutiques employés au cours des troubles respiratoires, les recherches destinées à éclaircir les mécanismes respiratoires physiologiques et leurs déviations patho-physiologiques au cours de "détresse' respiratoire ont une importance pratique considérable.

Un total de 172 enfants venus à terme et en bonne santé, après une grossesse sans histoire, d'une longueur habituelle et un accouchement à présentation normale sans complications, a servi de sujets aux diverses études.

La taille des sujets à étudier et leur manque de coopération ont posé des problèmes de méthodes particuliers. Des procédés et des méthodes appropriés permettant des mesures reproductibles et exactes ont été développés ou adaptés à l'étude de la mécanique respiratoire, de la capacité fonctionnelle résiduelle, de la ventilation pulmonaire, de la capacité de diffusion et de l'échange gazeux pulmonaire. Enfin, on a dû étudier la validité du sang capillarie pour remplacer le sang artériel. Le résultat étant négatif en ce qui concerne $\mathrm{PO}_{2}$, on a dû développer un procédé sans danger permettant de prélever du sang artériel sans troubler les conditions stables.

Le début de la respiration et l'aération initiale des poumons sont caracterisés par l'apparition de forces de très haute résistance, dues surtout probablement, à la haute tension de surface. Ensuite, l'accomodation (compliance) pulmonaire augmente tandis que la résistance pulmonaire et le travail 
inspiratoire diminuent, la vitesse de ces changements étant très élevée au début et diminuant ensuite.

Une heure après la naissance, la capacité fonctionnelle résiduelle atteint de 40 à 80 $\mathrm{ml}$ et présente un rapport avec la compliance pulmonaire semblable à ce qu'il sera plus tard dans la vie. Après 24 heures, les changements sont insignifiants.

A la naissance, il y a hypoxémie, rétention de $\mathrm{CO}_{2}$ et accumulation d'acides fixes, c'està-dire acidose respiratoire et métabolique. La composante respiratoire d'acidose est abolie à 30 minutes, en moyenne, et l'acidose métabolique à 24 heures. Le $\mathrm{P}_{\mathrm{CO}_{2}}$ atteint un taux minimal d'environ $33 \mathrm{~mm} \mathrm{Hg}$ à 24 heures et augmente légèrement jusqu'à 36 $\mathrm{mm} \mathrm{Hg}$ à 7 jours. Cette hyperventilation semble être compensée par une hypobasémie correspondante qui diminue par la suite, en suivant de près l'augmentation de $\mathrm{P}_{\mathrm{CO}_{2}}$. Cette régulation présente une analogie frappante avec les changements survenant durant et après l'adaptation à l'altitude.

La tension de l'oxygène artériel augmente rapidement jusqu'à atteindre la moyenne de $73 \mathrm{~mm} \mathrm{Hg}$, à l'âge de 5 heures. Ensuite, aucun autre changement de quelque signification n'intervient. Elle est donc significativement plus basse que chez l'adulte normal.

A l'âge de 55 minutes le shunt veinoartériel vrai (anatomique) représente environ $24 \%$ du débit cardiaque. De 5 heures jusqu' à l'âge de 7 jours il varie entre 8 et $11 \%$. Cette réduction survenant au cours des premières heures de la vie correspond vraisemblablement à la forte diminution ou suppression des shunts veino-artériels au niveau des communications foetales.

Parmi les différentes variables étudiées, lors de la mesure de la capacité de diffusion, sous "steady state", à l'âge de 24 heures et de 7 jours, seules les variables suivantes montrent un changement statistiquement significatif pendant cette période: fréquence cardiaque, fréquence respiratoire, ventilation pulmonaire $\left(\mathrm{V}_{E}\right)$, quotient respiratoire $(\mathrm{R})$, rapport entre espace mort et volume courant $\left(\mathrm{V}_{\mathrm{D}} / \mathrm{V}_{\mathrm{T}}\right)$, rapport entre ventilation alvéolaire et élimination de $\mathrm{CO}_{2}\left(\mathrm{~V}_{\mathrm{A}} / \mathrm{V}_{\mathrm{CO}_{2}}\right)$, capacité pulmonaire de diffusion pour $\mathrm{CO}$, rapport entre shunt veino-artériel vrai (anatomique) et shunt veino-artériel total (contamination veineuse) (voir Tableau IV).

La ventilation alvéolaire par rapport à la consommation d'oxygène, $\mathrm{V}_{\mathrm{A}} / \mathrm{V}_{\mathrm{O}_{2}}$, ainsi que la capacité pulmonaire de diffusion pour $\mathrm{CO}$ par rapport à la consommation d'oxygène, et par $\mathrm{m}^{2}$ de surface corporelle, et le $\overline{\mathrm{P}}_{\mathrm{AO}_{2}}-$ $\overline{\mathrm{P}}_{\mathrm{CO} 2}$, sont du même ordre que chez l'adulte normal au repos.

La différence de tension d'oxygène alvéoloartériel $\left(\overline{\mathrm{P}}_{\mathrm{AO}_{2}}-\mathrm{P}_{\mathrm{aO}_{2}}\right)$ est de l'ordre de 30 $\mathrm{mm} \mathrm{Hg}$, et reste à peu près inchangée entre 24 heures et 7 jours. Elle est ainsi significativement plus élevée que chez l'adulte normal. Elle est due, à parts approximativement égales, à un shunt veino-artériel anatomique et à une inégalité du rapport ventilation/perfusion, (contribution venant des alvéoles avec rapport ventilation/perfusion diminué). Après l'adaptation initiale, l'importance de la contamination veineuse due à l'inégalité ventilation/perfusion par rapport au shunt veinoartériel total, diminue pendant la première semaine de vie.

En accord avec ces résultats, on a évalué le rapport ventilation/perfusion total à 0.65 en moyenne avec une légère tendance à augmenter pendant la période d'observation.

Les changements de la plupart des variables, suivis d'une manière continue de la naissance à 7 jours, peuvent être exprimés par des fonctions logarithmiques de l'âge montrant que les changements adaptatifs se déroulent le plus rapidement au stade initial.

Même à l'âge de 7 jours, le poumon du nouveau-né n'a pas encore atteint la même efficacité quant à l'échange d'oxygène, que celui de l'adulte normal. 


\section{ZUSAMMENFASSUNG}

Während der Schwangerschaft besorgt die Placenta den äusseren Gasaustausch und Stoffwechsel des Feten. Mit dem Übergang vom Leben im Wasser, d.h. in utero, in unsere Luftatmosphäre bei der Geburt entfällt der Placentarkreislauf. Diese Umstellung setzt das unmittelbare Einsetzen einer neuen autonomen Organfunktion voraus, die der Lungen, zum Zwecke des äusseren Gasaustauschs. Dieser Funktionswandel der Lunge ist eng mit tiefgreifenden Umstellungen und Anpassungen des Kreislaufs verbunden.

Ziel der vorliegenden Untersuchungen war es, einige der bei der Entwicklung des pulmonalen Gasaustauschs beteiligten Faktoren und Funktionen klarzulegen und ihre Effektivität während der Anpassungsperiode im Vergleich zum gesunden Erwachsenen zu untersuchen. Obwohl die dringlichsten und raschesten Veränderungen im Verlauf dieses Anpassungsvorgangs während der ersten Sekunden und Minuten des extrauterinen Lebens erfolgen, erstrecken Sie sich weit über diesen Zeitabschnitt hinaus. Die vorliegenden Untersuchungen wurden daher auf die gesamte Neonatalperiode, d. h. die erste Lebenswoche, ausgedehnt. Dies erschien umso wichtiger, als unsere Kenntnisse in Bezug auf den späteren Teil der postnatalen Adaptation spärlich sind bzw. entsprechende Untersuchungsresultate gänzlich fehlen. Besonderes Gewicht wurde auf die Veränderungen der Lungenfunktion während der ersten Lebenswoche gelegt.
Der überwiegende Teil der immer noch hohen und während der letzten Jahrzehnte wenig veränderten Neugeborenensterblichkeit beruht auf Schwierigheiten in der Ausbildung eines adäquaten pulmonalen Gasaustausches. Durch Verbesserung der diagnostischen Möglichkeiten und der Grundlagen zur Beurteilung therapeutischer Massnahmen haben alle Untersuchungen, die zu verbesserter Einsicht in das physiologische und pathophysiologische Geschehen bei der normalen und gestörten Anpassung der Lungenatmung führen, unmittelbare praktische Bedeutung.

Im Ganzen wurden 172 gesunde Kinder untersucht, die nach unauffälliger Schwangerschaft von normaler Dauer und nach unkomplizierter vaginaler Entbindung geboren worden waren. Der klinische Verlauf während der ersten Lebenswoche war bei allen Kindern unauffällig.

Die Grösse der Probanden und das Fehlen jeglicher Möglichkeit zur Mitarbeit in dieser Altersgruppe stellen besondere methodologische Probleme. Brauchbare Verfahren und Methoden mit ausreichender Reproduzierbarkeit und Validität wurden zum Studium von Lungenmechanik, funktioneller Residualkapazität, Lungenventilation, Diffusionskapazität und intrapulmonalem Gasaustausch entwickelt, oder für die besonderen Verhältnisse modifiziert. Da Kapillärblut kein zuverlässiger Ersatz für arterielles Blut zum Studium der Atemgase, insbesondere in Bezug 
auf $\mathrm{PO}_{2}$ ist, musste ein risikofreies Verfahren zur Gewinnung von arteriellem Blut ohne Störung der steady-state Bedingungen entwickelt bzw. angepasst werden.

Beim Einsetzen der Atmung und der initialen Belüftung der Lunge kommt es zum Auftreten von hohen Widerstandskräften, denen wahrscheinlich hauptsächlich hohe Oberflächenspannungen zugrunde liegen. Im weiteren Verlauf nimmt die Lungencompliance $\mathrm{zu}$, während der Lungenwiderstand und die inspiratorische Atemarbeit abnehmen. Diese Veränderungen erfolgen am schnellsten im Anfang und nehmen allmählich ab.

Innerhalb von 60 Minuten nach der Geburt beträgt die funktionelle Residualkapacität 40-80 $\mathrm{ml}$. Die spezifische Lungencompliance $\left(\mathrm{C}_{\mathrm{L}} / \mathrm{FRC}\right)$ steigt während der ersten 24 Stunden und erreicht Werte, die mit denen des gesunden Erwachsenen identisch sind.

Bei der Geburt hat des Neugeborene eine Hypoxämie, $\mathrm{CO}_{2}$-Retention und Anhäufung fixer Säuren, d.h. eine respiratorische und metabolische Acidose. Die respiratorische Komponente ist im Durchschnitt 30 Minuten nach Geburt und die metabolische Acidose im Alter von 24 Stunden ausgeglichen. $\mathrm{PaCO}_{2}$ erreicht im Alter von 24 Stunden mit $33 \mathrm{~mm}$ $\mathrm{Hg}$ ein Minimum und steigt dann allmählich auf $36 \mathrm{~mm} \mathrm{Hg}$ am 8. Lebenstag an. Diese Hyperventilation scheint durch eine entsprechende sekundäre Hypobasämie kompensiert zu werden, die im Lauf der ersten Lebenswoche zurückgeht und dabei eng dem Anstieg des $\mathrm{PCO}_{2}$ folgt. Diese Anpassung zeigt eine auffällige Ähnlichkeit mit den Veränderungen, die während und nach Höhenanpassung beim Erwachsenen beobachtet werden können.

Die arterielle Sauerstoffspannung steigt innerhalb von 5 Stunden auf im Durchsnitt $73 \mathrm{~mm} \mathrm{Hg}$ an und zeigt danach während der ersten Lebenswoche keine signifikanten Veränderungen. $\mathrm{P}_{\mathrm{aO}}$ ist demnach signifikant niedriger als beim gesunden Erwachsenen.
Die Kurzschlussblutmenge auf Grund von anatomischen Rechts-Links-Shunts beträgt 55 Minuten nach der Geburt im Durchschnitt ca $24 \%$ des Minutenvolumens, sinkt innerhalb der ersten 5 Stunden auf knapp $10 \%$ und zeigt während des Restes der ersten Lebenswoche nur geringfügige Veränderungen. Ursache der deutlichen Abnahme zwischen 55 Minuten und 5 Stunden dürfte das Aufhören oder zumindesten eine deutliche Verminderung von Rechts-Links-Shunts durch fetale Kreislaufverbindungen (Foramen ovale, Ductus arteriosus Botalli) sein.

Von den verschiedenen Variablen, die im Zusammenhang mit der Diffusionskapazität der Lungen unter steady-state-Bedingungen im Alter von 24 Stunden und 7 Tagen bestimmt wurden, zeigen nur die folgenden eine statistisch signifikante Veränderung im Verlauf dieser Periode: Herzfrequenz, respiratorischer Quotient (R) und Verhältnis anatomischer Shunt/gesamte venöse Kurzschlussdurchblutung einen Anstieg; Atemfrequenz, Minutenventilation $\left(\dot{V}_{E}\right)$, Verhältnis alveoläre Ventilation/ $\mathrm{CO}_{2}$-Ausscheidung $\left(\mathrm{V}_{\mathrm{A}} / \mathrm{V}_{\mathrm{CO}}\right)$, Verhältnis physiologischer Tot$\mathrm{raum} /$ Atemzugvolumen $\left(\mathrm{V}_{\mathrm{D}} / \mathrm{V}_{\mathrm{T}}\right)$, Diffusionskapazität für $\mathrm{CO}$, sowie die gesamte venöse Kurzschlussdurchblutung eine Abnahme (siehe Tabelle IV).

Die alveoläre Ventilation im Verhältnis zum Sauerstoffverbrauch $\left(\mathrm{V}_{\mathrm{A}} / \mathrm{V}_{\mathrm{O}_{2}}\right)$, der physiologische Totraum im Verhältnis zum Atemzugvolumen $\left(\mathrm{V}_{\mathrm{D}} / \mathrm{V}_{\mathrm{T}}\right)$, die Diffusionskapazität für CO im Verhältnis zum Sauerstoffverbrauch, zur alveolären Ventilation und zur Körperoberfläche, sowie $\overline{\mathrm{P}}_{\mathrm{AO}}-$ $\overline{\mathrm{P}}_{\mathrm{CO}_{2}}$ sind in derselben Grössenordnung wie beim gesunden Erwachsenen unter Ruhebedingungen.

Die alveolo-arterielle Sauerstoffdruckdifferenz bei Luftatmung liegt in der Grössenordnung von $30 \mathrm{~mm} \mathrm{Hg}$ und ändert sich kaum vom Ende des ersten Lebenstages bis zum Ende der ersten Woche. Sie ist damit deutlich höher als beim gesunden Erwachsenen. 
Anatomischer Rechts-Links-Shunt und venöse Beimischung von Alveolen mit niedrigem Ventilations/Perfusions-Verhältnis scheinen in nahezu gleichem Ausmass zu dieser Differenz beizutragen. Der Anteil auf Grund ungleichen Ventilations/Perfusions-Verhältnisses nimmt im Lauf der ersten Lebenswoche $a b$.

In Übereinstimmung mit diesen Ergebnissen ergab sich für das Gesamt-Ventilations/Perfusions-Verhältnis ein Durchschnittswert von 0.65 mit einer geringen Steigerungstendenz während der ersten Lebenswoche.
Die Veränderung der meisten der von der Geburt bis zum achten Lebenstag systematisch untersuchten Variabeln kann als logarithmische Funktion des Alters ausgedrückt werden (Tabelle III). Dies zeigt, dass die Anpassungsvorgänge am raschesten im Initialstadium erfolgen.

Selbst im Alter von 7 Tagen hat die Neugeborenenlunge in Hinsicht auf den pulmonalen Sauerstoffaustausch noch nicht die gleiche Effektivität erreicht wie die des Erwachsenen. 


\section{REFERENCES}

Adams, F. H., Fujiwara T. and Rowshan, G.: The nature and origin of the fluid in the fetal lamb lung. J Pediat 63, 881, 1963 (a).

Adams, F. H., Moss, A. J. and Fagan, L.: The tracheal fluid in the fetal lamb. Biol Neonat 5, 151, 1963 (b).

Arcilla, R. A., OH, W., Wallgren, G., Hansson, J. S., Gessner, I. H., and Lind, J.: Quantitative studies of the human neonatal circulation. II. Hemodynamic findings in early and late clamping of the umbilical cord. Acta Paediat Scand suppl. 179, 23, 1967.

Auld, P. A. M., Nelson, N. M., Cherry, R. B., Rudolph, A. J. and Smith, C. A.: Measurement of thoracic gas volume in the newborn infant. J Clin Invest 42, 476, 1963.

Avery, M. E., Chernick, V., Dutton, R. S. and Permutt, S.: Ventilatory response to inspired carbon dioxide in infants and adults. J Appl Physiol 18, 895, 1963.

Boston, R. W., Humphreys, P. W., Reynolds, E. O. R. and Strang, L. B.: Lymph-flow and clearance of liquid from the lungs of the foetal lamb. Lancet 2, 473, 1965.

Burnard, E. D., Grauaug, A. and Gray, R. E.: Cardiac output in the newborn infant. Clin Sci 31, 121, 1966.

Carmel, J. A., Friedman, F. and Adams, F. H.: Fetal tracheal ligation and lung development. Amer J Dis Child 109, 452, 1965.

Chu, J. S., Dawson, P., Klaus, M. and Sweet, A. Y.: Lung compliance and lung volume measured concurrently in normal full-term and premature infants. Pediatrics 34, 525, 1964.

Clark, L. C. Jr.: Monitor and control of blood and tissue oxygen tensions. Trans Amer Soc Artif Intern Organs, 2, 41, 1956.
Cook, C. D., Cherry, R. B., O'Brien, D., Karlberg, P. and Smith, C. A.: Studies of respiratory physiology in the newborn infant. I. Observations on normal premature and fullterm infants. J Clin Invest 34, 975, 1955.

Cook, C. D., Drinker, P. A., Jacobson, H. N., Levison, H. and Strang, L. B.: Control of pulmonary blood flow in the foetal and newly born lamb. J Physiol (London) 169, 10, 1963.

Cook, C. D., Sutherland, J. M., Segal, S., Cherry, R. B., Mead, J., Mcilroy, M. B. and Smith, C. A.: Studies of respiratory physiology in the newborn infant. III. Measurements of mechanics of respiration. J Clin Invest 36, 440, 1957.

Dawes, G. S.: Changes in the circulation at birth and effects of asphyxia. In: Recent advances in paediatrics, edited by D. Gairdner, J. \& A. Churchill Ltd. London 1958.

Dawes, G. S.: Oxygen supply and consumption in the late fetal life, and the onset of breathing at birth. In: Handbook of physiology. Section 3. Respiration. Volume II, edited by W. O. Fenn and H. Rahn. Washington, D. C. 1965, p. 1313.

Dawes, G. S. and Mott, J. C.: The vascular tone of the foetal lung. J Physiol (London) 164, 465, 1962.

Dawes, G. S., Mott, J. C., Widdicombe, J. G. and Wyatt, D. G.: Changes in the lungs of the newborn lamb. J Physiol (London) 121, 141, 1953.

Derom, R.: Anaerobic metabolism in the human fetus. I. The normal delivery. Amer J Obstet Gynec 89, 241, 1964.

Driscoll, S. G. and Smith, C. A.: Neonatal pulmonary disorders. Ped Clin N Amer 9, 325, 1962

Drorbaugh, J. E., Segal, S., Sutherland, J. M., Oppé, T. E., Cherry, R. B. and Smith, C. A.: Compliance of lung during first week of life. Amer J Dis Child 105, 63, 1963. 
DuBois, A. B., Botelho, S. Y. and Comroe, J. H. Jr.: A new method for measuring airway resistance in man using a body plethysmograph: values in normal subjects and in patients with respiratory disease. J Clin Invest 35, 327, 1956.

Engström, L., Karlberg, P., Rooth, G. and Tunell, R.: The onset of respiration. A study of respiration and changes in blood gases and acid-base balance. Association for the Aid of Crippled Children, New York 1966.

Filley, G. F., MacIntosh, D. J. and Wright, G. W.: Carbon monoxide uptake and pulmonary diffusing capacity in normal subjects at rest and during exercise. J Clin Invest 33, 530, 1954.

Friedemann, T. E. and Haugen, G. E.: Pyruvic acid. II. The determination of keto acids in blood and urine. J Biol Chem 147, 415, 1943.

Gessner, I., Krovetz, L. J., Benson, R. W., Prystowsky, H., Stenger, V. and Eitzman, D. V.: Hemodynamic adaptations in the newborn infant. Pediatrics 36, 752, 1965.

Gribetz, I., Frank, N. R. and Avery, M. E.: Static volume-pressure relations of excised lungs of infants with hyaline membrane disease, newborn and stillborn infants. J Clin Invest 38, 2168, 1959.

Gruenwald, P., Johnson, R. P., Hustead, R. F. and Clements, J. A.: Correlation of mechanical properties of infant lungs with surface activity of extracts. Proc Soc Exp Biol Med 109, 369, 1962.

Howatt, W. F., Humphreys, P. W., Normand, I. C. S. and Strang, L. B.: Ventilation of liquid by the fetal lamb during asphyxia. J Appl Physiol 20, 496, 1965.

Huckabee, W. E.: Control of concentration gradients of pyruvate and lactate across cell membranes in blood. J Appl Physiol 9, 163, 1956.

James, L. S.: Physiologic adjustment at birth. Anesthesiology 26, 501, 1965.

Karlberg, P., Adams, F. H., Geubelle, F. and Wiallgren, G.: Alteration of the infant's thorax during vaginal delivery. Acta Obst Gyn Scand 41, 223, 1962.

Karlberg, P., Cherry, R. B., Escardó, F. and Koch, G.: Respiratory studies in newborn infants. I. Apparatus and methods for studies of pulmonary ventilation and the mechanics of breathing. Principles of analysis in mechanics of breathing. Acta Paediat Scand 49, 345, 1960.
Kellogg, R. H.: The role of $\mathrm{CO}_{2}$ in altitude acclimatization. In: The regulation of human respiration, edited by D. I. C. Cunningham and B. B. Lloyd. Blackwell Scientific Publications, Oxford 1963, p. 379.

Klaus, M., Tooley, W. H., Weaver, K. H. and Clements, J. A.: Functional residual capacity in newborn infants measured by a rapid physical method. Amer J Dis Child 100, 482, 1960.

Klaus, M., Tooley, W. H., Weaver, K. H. and Clements, J. A.: Lung volume in the newborn infant. Pediatrics 30, 111, 1962.

Koch G.: Comparison of carbon dioxide tension, $\mathrm{pH}$ and standard bicarbonate in capillary blood and in arterial blood with special respect to relations in patients with impaired cardiovascular and pulmonary function and during exercise. Scand $\mathrm{J}$ Clin Lab Invest 17, 223, 1965.

Koch, G. and Wendel, H.: Comparison of pH, carbon dioxide tension, standard bicarbonate and oxygen tension in capillary blood and in arterial blood during the neonatal period. Acta Paediat Scand 56, 10, 1967 (a).

Koch, G. and Wiendel, H.: Zur Frage der Gewinnung von arteriellem Blit in der Neugeborenenperiode. Erfahrungen bei 121 Verweilkathetern der A. umbilicalis. Mschr Kinderheilk 115, 82, 1967 (b).

Lind, J.: Physiological adaptation to the placental transfusion. The Eleventh Blackader Lecture. Can Med Ass J 93, 1091, 1965.

Lind, J., Stern, L. and Wegelius, C.: Human fetal and neonatal circulation. Charles C. Thomas, Springfield Ill., 1964.

Lind, J. and Wegelius, C.: Human fetal circulation: changes in the cardiovascular system at birth and disturbances in the postnatal closure of the foramen ovale and ductus arteriosus. Cold Spring Harbor Symposia on Quantitative Biology 19, 109, 1954.

Linderholm, H.: On the significance of $\mathrm{CO}$ tension in pulmonary capillary blood for determination of pulmonary diffusing capacity with the steady state CO method. Acta Med Scand 156, 413, 1957.

Linderholm, H.: A micromethod for the determination of carbon monoxide in blood. Acta Physiol Scand 64, 372, 1965.

Linderholm, H. and Sjöstrand, T.: Determination of carbon monoxide in small gas volumes. Acta Physiol Scand 37, 240, 1956. 
Marshall, R. and DuBois, A. B.: The measurement of the viscous resistance of the lung tissues in normal man. Clin Sci 15, 161, 1956.

Metcalfe, J.: The oxygen supply of the foetus. In: Development of the lungs, edited by A. V. S. de Reuck and R. Porter. J. \& A. Churchill Ltd. London 1967, p. 258.

Nelson, N. M., Prod'hom, L. S., Cherry, R. B., Lipsitz, P. J. and Smith, C. H.: Pulmonary function in the newborn infant. I. Methods - ventilation and gaseous metabolism. Pediatrics 30, 963, 1962 (a).

Nelson, N. M., Prod'hom, L. S., Cherry, R. B., Lipsitz, P. J. and Smith, C. A.: Pulmonary function in the newborn infant. II. Perfusion - estimation by analysis of the arterial-alveolar carbon dioxide difference. Pediatrics 30, 975, 1962 (b).

Nelson, N. M., Prod'hom, L. S., Cherry, R. B., Lipsitz, P. J. and Smith, C. A.: Pulmonary function in the newborn infant. V. Trapped gas in the normal infant's lung. J Clin Invest 42, 1850, 1963 (a).

Nelson, N. M., Prod'hom, L. S., Cherry, R. B., Lipsitz, P. J. and Smith, C. A.: Pulmonary function in the newborn infant - the alveolar-arterial oxygen gradient. J Appl Physiol 18, 534, 1963 (b).

Oh, W., Wallgren, G., Hanson, J. S. and Lind, J.: The effects of placental transfusion on respiratory mechanics of normal term newborn infants. Pediatrics 40, 6, 1967.

Plank, J.: A morphological contribution to the development of the human lung: observations in the non-retracted lung. In: Development of the lung, edited by A. V. S. de Reuck and R. Porter, J. \& A. Churchill Ltd, London 1967, p. 156.

Polgar, G.: Opposing forces to breathing in newborn infants. Biol Neonat 11, 1, 1967.

Polgar, G. and Kong, G. P.: The nasal resistance of newborn infants. J Pediat 67, 857, 1965.

Polgar, G. and String, S. T.: The viscous resistance of the lung tissues in newborn infants. J Pediat 69, 787, 1966.

Potter, E. L.: Pulmonary pathology in the newborn. In: Advances in pediatrics, edited by S. Z. Levine. The Year Book Publishers, Inc, Chicago 1953, p. 157.

Prod'hom, L. S., Levison, H., Cherry, R. B., Drorbaugh, J. E., Hubbell, J. R. Jr. and Smith, C. A.: Adjustment of ventilation, intrapulmonary gas ex- change and acid-base balance during the first day of life. Normal values in well infants of diabetic mothers. Pediatrics 33, 682, 1964.

Rahn, H. and Farhi, L. E.: Ventilation-perfusion relationship. In: Pulmonary structure and function, edited by A. V. S. de Reuck and M. O'Connor. J. \& A. Churchill, London 1962, p. 139.

Rahn, H. and Farhi, L. E.: Ventilation, perfusion and gas exchange - the $\dot{V}_{\mathrm{A}} / \mathrm{Q}$ concept. In: Handbook of physiology. Section 3. Respiration. Vol. I, edited by W. O. Fenn and H. Rahn. Washington I. C. American Physiological Society, 1964, p. 735.

Riegel, K. P.: personal communication.

Scholander, P. F.: Analyzer for accurate estimation of respiratory gases in one-half cubic centimeter samples. J Biol Chem 167, 235, 1947.

Severinghaus, J. W. and Bradley, A. F.: Electrodes for blood $\mathrm{PO}_{2}$ and $\mathrm{PCO}_{2}$ determination. J Appl Physiol $13,515,1958$.

Siggaard-Andersen, O.: Blood acid-base alignment nomogram. Scand J Clin Lab Invest 15, 211, 1963.

Siggaard-Andersen, O., Engel, K., Jørgensen, K. and Astrup, P.: A micromethod for determination of $\mathrm{pH}$, carbon dioxide tension, base excess and standard bicarbonate in capillary blood. Scand J Clin Lab Invest 12, 172, 1960.

Smith, C. A.: The physiology of the newborn infant. Charles C. Thomas, Springfield, Ill., 1959, p. 33.

Stahlman, M. T.: Pulmonary ventilation and diffusion in the human newborn infant. J Clin Invest 36, 1081, 1957.

Strang, L. B.: Uptake of liquid from the lungs at the start of breathing. In: Development of the lung, edited by A. V. S. de Reuck and R. Porter. J. \& A. Churchill, Ltd, London 1967, p. 348.

Strang, L. B. and McGrath, M. W': Alveolar ventilation in normal newborn infants studied by air wash-in after oxygen breathing. Clin Sci 23, 129, 1962.

Swyer, P. R., Reiman, R. C. and Wright, J. J.: Ventilation and ventilatory mechanics in the newborn. J Pediat 56, 612, 1960.

Tooley, W. H., Klaus, M., Weaver, K. H. and Clements, J. A.: The distribution of ventilation in normal newborn infants. Am J Dis Child 100: 119, 1960.

Wulf, H.: Der Gasaustausch in der Placenta. Mschr Kinderheilk 115, 130, 1967. 


\section{APPENDIX}

TABLE 1.

Obstetrical Data (VI).

\begin{tabular}{|c|c|c|c|c|c|c|c|c|}
\hline \multirow[b]{2}{*}{$\begin{array}{l}\text { No. } \\
\text { sex }\end{array}$} & \multirow{2}{*}{$\begin{array}{l}\text { Birth- } \\
\text { weight } \\
\text { (g) }\end{array}$} & \multirow[b]{2}{*}{$\begin{array}{l}\text { Height } \\
(\mathrm{cm})\end{array}$} & \multirow{2}{*}{$\begin{array}{l}\text { Age of } \\
\text { mother } \\
\text { (ys) }\end{array}$} & \multirow[b]{2}{*}{ Parity } & \multirow{2}{*}{$\begin{array}{c}\text { Gest. } \\
\text { age } \\
\text { (weeks) }\end{array}$} & \multirow{2}{*}{$\begin{array}{c}\text { Duration } \\
\text { labour } \\
\text { (hs) }\end{array}$} & \multicolumn{2}{|c|}{ Anaesthesia } \\
\hline & & & & & & & $\begin{array}{l}\text { Nitrous } \\
\text { oxide }\end{array}$ & $\begin{array}{l}\text { Trichlor- } \\
\text { ethylene }\end{array}$ \\
\hline $1 \mathrm{M}$ & 3480 & 52 & 34 & 2 & 42 & 3.5 & + & + \\
\hline $2 \mathrm{~F}$ & 3290 & 52 & 24 & 1 & 41 & 3.7 & + & + \\
\hline $3 \mathrm{~F}$ & 2710 & 47 & 18 & 1 & 41 & 16.6 & + & + \\
\hline $4 \mathrm{~F}$ & 3290 & 52 & 19 & 1 & 39 & & + & - \\
\hline $5 \mathrm{M}$ & 3490 & 54 & 25 & 1 & 42 & 7.7 & + & + \\
\hline $6 \mathrm{M}$ & 4070 & 53.5 & 22 & 1 & 39 & & + & + \\
\hline $7 \mathrm{~F}$ & 4060 & 52.5 & 24 & 2 & 39 & & + & + \\
\hline $8 \mathrm{~F}$ & 3190 & 47 & 23 & 1 & 41 & 5.0 & + & + \\
\hline $9 \mathrm{M}$ & 3650 & 52.5 & 21 & 2 & 42 & 1.2 & 0 & 0 \\
\hline $10 \mathrm{~F}$ & 3370 & 50 & 30 & 2 & 39 & 10.9 & + & + \\
\hline $11 \mathrm{~F}$ & 3540 & 52 & 22 & 2 & 41 & & + & + \\
\hline $12 \mathrm{M}$ & 4000 & 54 & 26 & 2 & 41 & & + & + \\
\hline $13 \mathrm{~F}$ & 4460 & 52 & 25 & 1 & 42 & & - & + \\
\hline $14 \mathrm{~F}$ & 3000 & 51.5 & 28 & 1 & 39 & & + & + \\
\hline $15 \mathrm{~F}$ & 3190 & 50 & 22 & 1 & 40 & 3.3 & + & + \\
\hline $16 \mathrm{M}$ & 3850 & 52 & 27 & 2 & 41 & 2.4 & + & + \\
\hline $17 \mathrm{~F}$ & 3740 & 51 & 21 & 2 & 40 & 4.2 & + & + \\
\hline $18 \mathrm{~F}$ & 3120 & 50.5 & 25 & 1 & 40 & 2.8 & + & + \\
\hline $19 \mathrm{M}$ & 3200 & 50 & 24 & 1 & 39 & 3.6 & & \\
\hline $20 \mathrm{~F}$ & 3630 & 52 & 34 & 3 & 39 & 9.5 & + & + \\
\hline $21 \mathrm{M}$ & 4200 & 54 & 26 & 2 & 42 & 4.9 & 0 & 0 \\
\hline $22 \mathrm{M}$ & 4430 & 51.5 & 29 & 2 & 43 & 5.2 & + & - \\
\hline $23 \mathrm{~F}$ & 4170 & 55 & 24 & 1 & 42 & 5.9 & + & + \\
\hline $24 \mathrm{M}$ & 3610 & 53 & 20 & 1 & 41 & 7.1 & + & + \\
\hline $25 \mathrm{M}$ & 4260 & 54 & 17 & 1 & 41 & 4.2 & + & + \\
\hline $26 \mathrm{M}$ & 3880 & 49.5 & 25 & 3 & 41 & & + & + \\
\hline $27 \mathrm{M}$ & 3490 & 50 & 35 & 3 & 40 & 2.6 & + & + \\
\hline $28 \mathrm{M}$ & 3430 & 50 & 40 & 4 & 40 & 3.2 & + & - \\
\hline $29 \mathrm{~F}$ & 3830 & 53 & 22 & 1 & 40 & 8.1 & & \\
\hline $30 \mathrm{M}$ & 3530 & 52 & 26 & 1 & 39 & 7.6 & + & + \\
\hline $31 \mathrm{M}$ & 3720 & 51 & 24 & 1 & 40 & 6.1 & + & + \\
\hline $32 \mathrm{~F}$ & 3180 & 52 & 23 & 2 & 40 & & & \\
\hline $33 \mathrm{~F}$ & 2880 & 49 & 32 & 3 & 41 & 3.3 & + & + \\
\hline Mean & 3604 & 51.5 & 25.4 & 2 & 40.5 & 5.5 & & \\
\hline SD & 436 & 1.9 & 5 & 1 & 1.1 & 3.3 & & \\
\hline
\end{tabular}




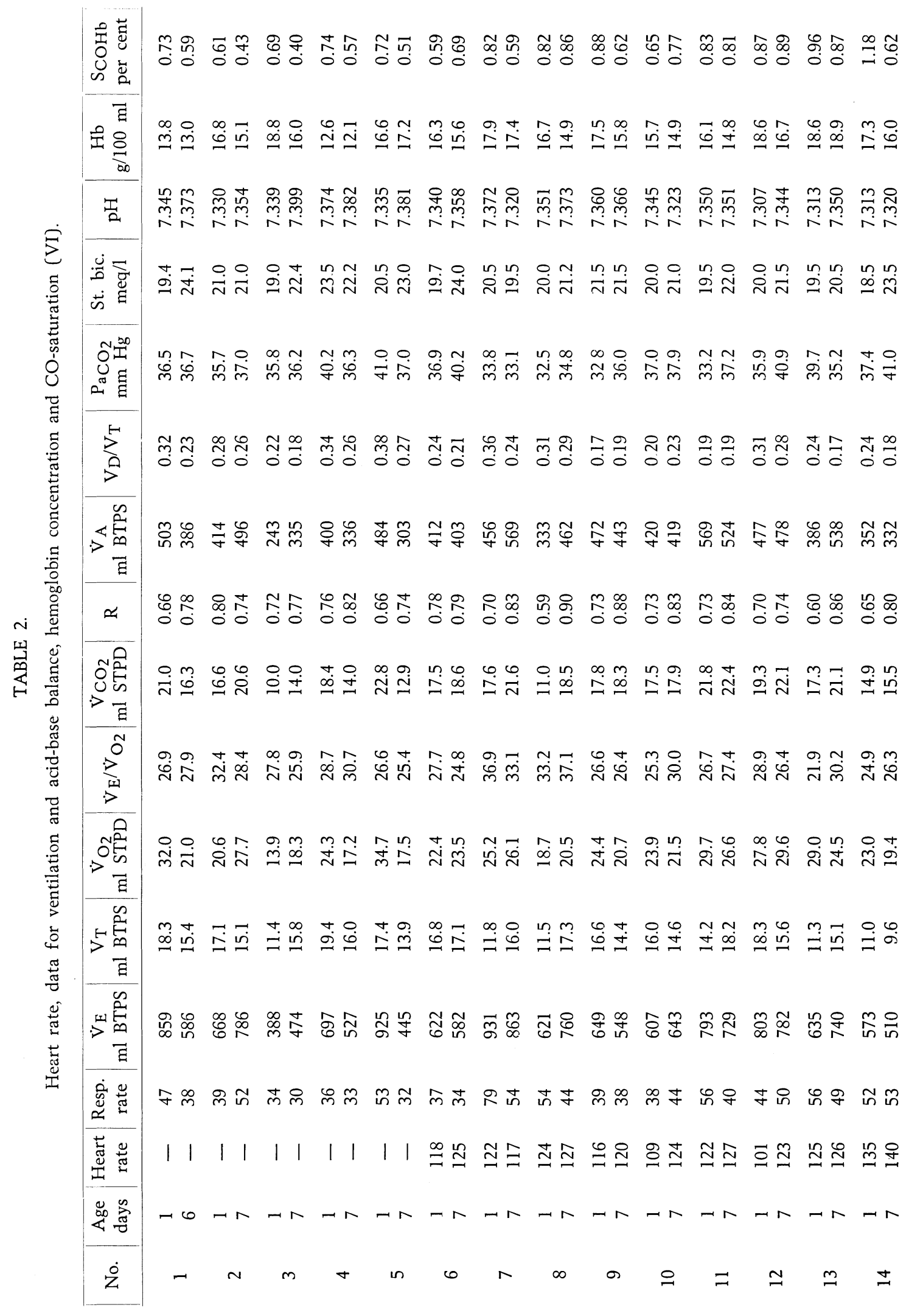


।

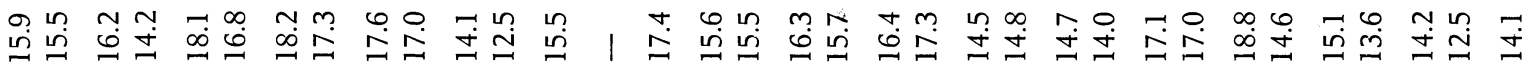

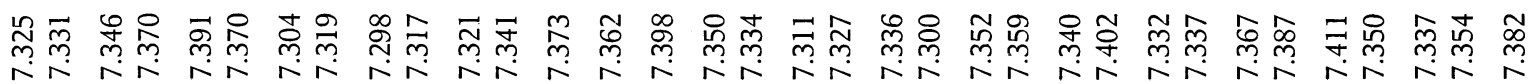

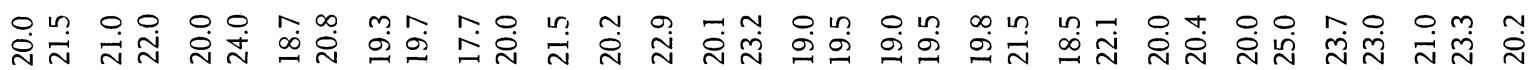

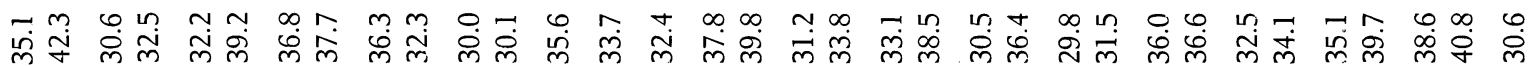

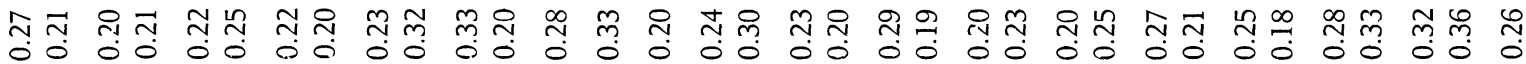

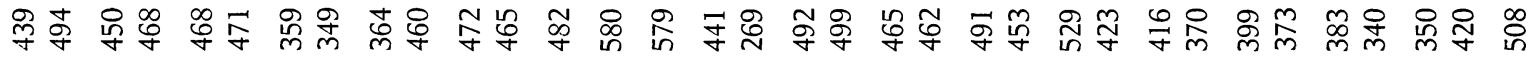

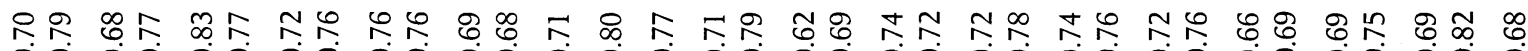

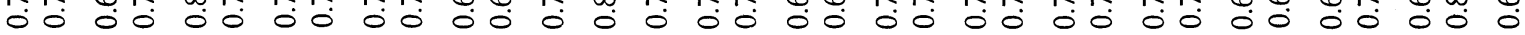

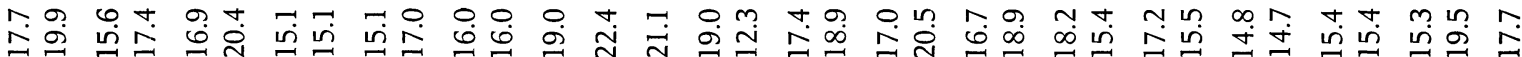

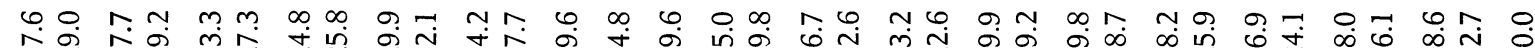

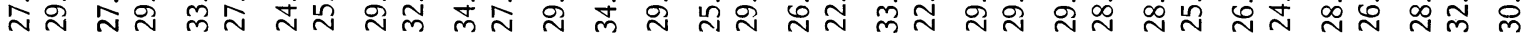

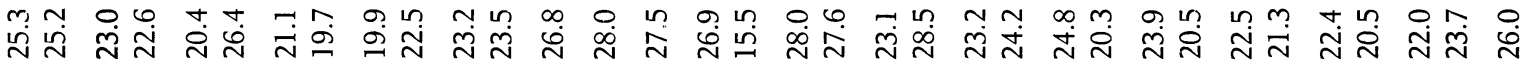

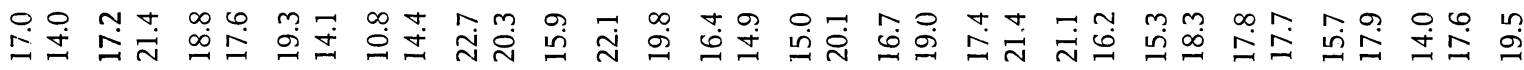

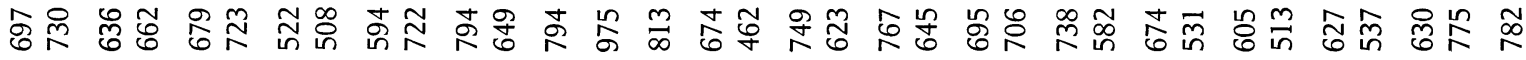
F 슬

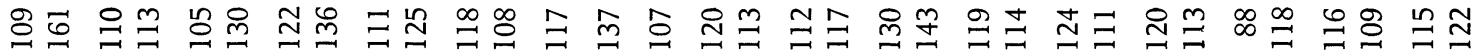

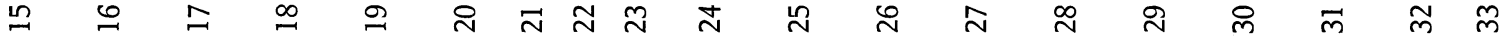




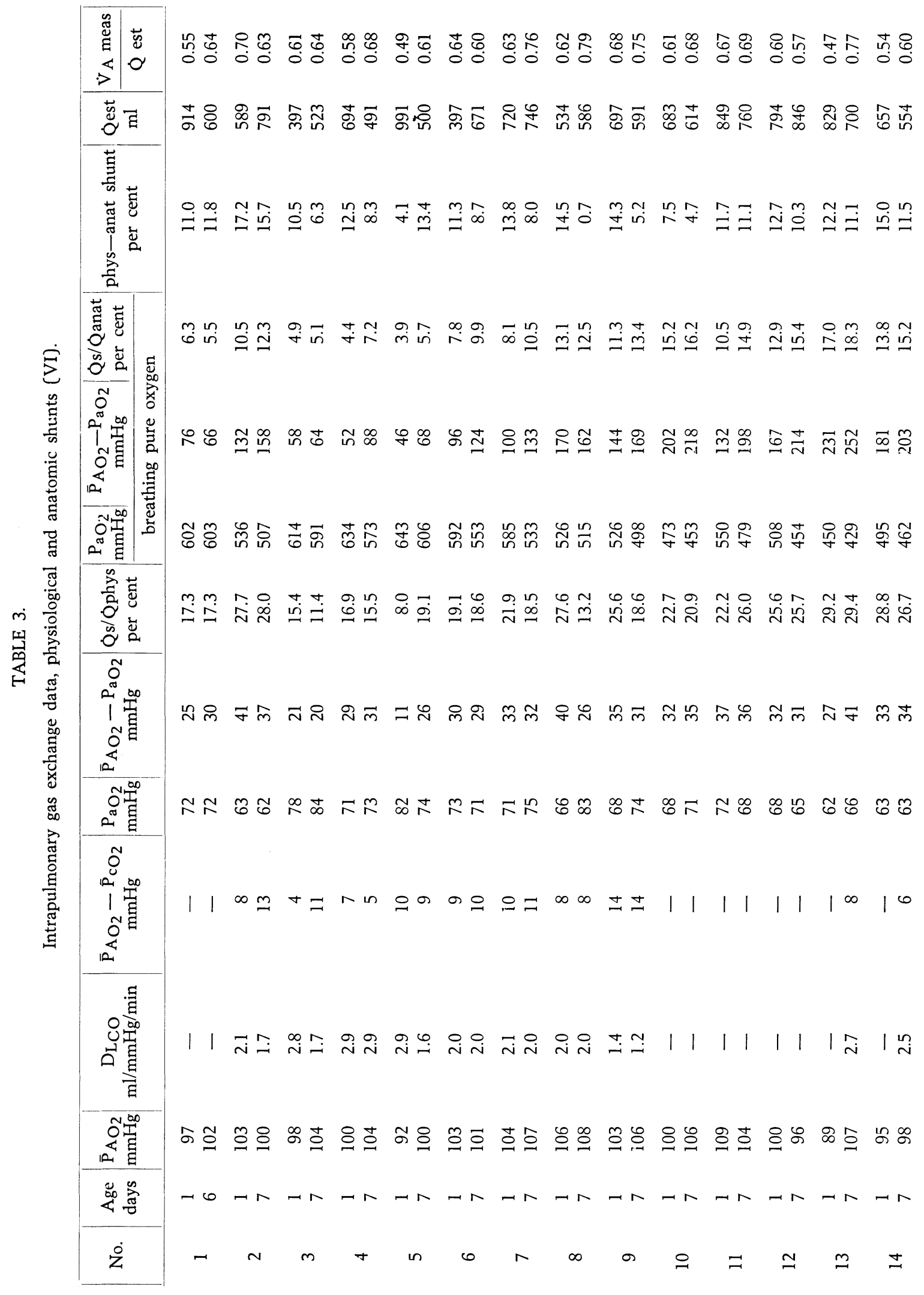




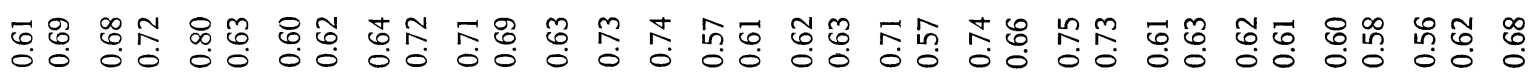

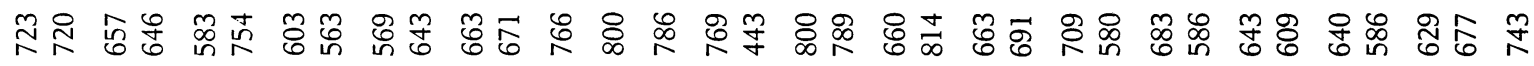

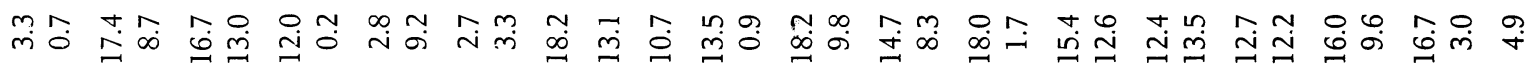

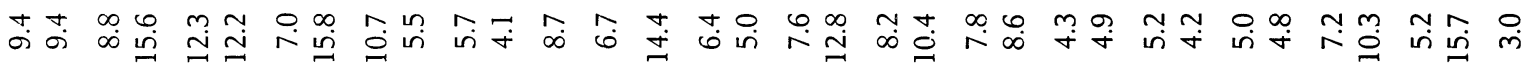

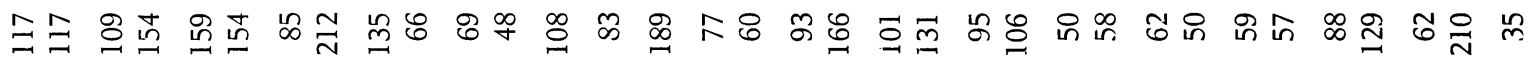

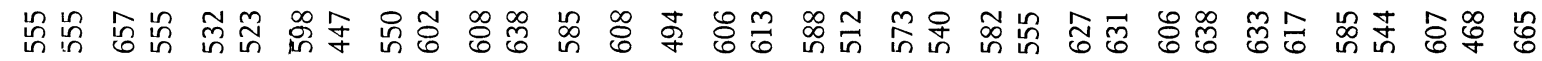

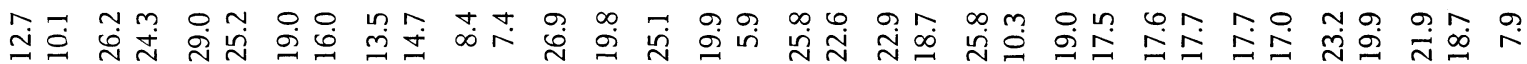

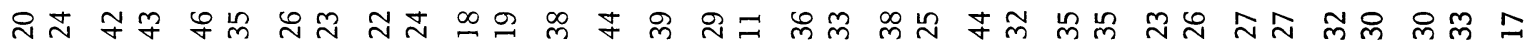
ஃ

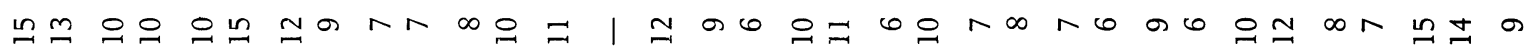

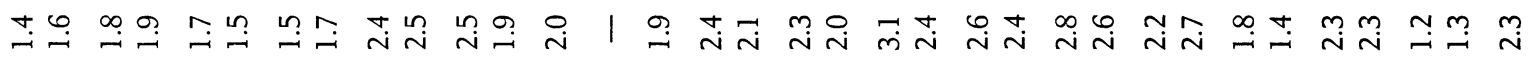

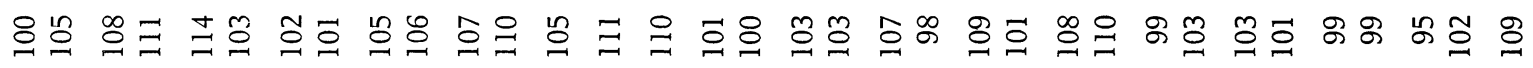

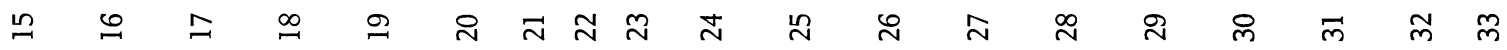


- 